\title{
Terrestrial vertebrate biodiversity and intensive forest management in the U.S.
}

Stephen Demarais, Department of Wildlife, Fisheries, and Aquaculture, Mississippi State University, Mississippi State, MS, USA 39762

Jacob P. Verschuyl, National Council for Air and Stream Improvement, Anacortes, WA, USA 98221

Gary J. Roloff, Department of Fisheries and Wildlife, Michigan State University, East Lansing, MI, USA 48824

Darren A. Miller, Weyerhaeuser Company, Columbus, MS, USA 39704

T. Bently Wigley, National Council for Air and Stream Improvement, Clemson, SC, USA 29634

\begin{abstract}
In the United States, intensively managed forests (IFM) comprise approximately $9 \%$ (27.9 million ha) of total forest area. These forests are primarily in highly productive areas and are managed primarily for wood and fiber production. Intensively managed forests provide both opportunities and constraints for conservation of vertebrate biodiversity. However, because a comprehensive review of these opportunities and limitations within the U.S. is lacking, we reviewed effects of typical silvicultural management regimes within IFM on terrestrial vertebrate species. The typical silvicultural regime in IFM includes practices associated with establishing forest management units (stands), weed control, intermediate thinning, and final harvest. Effects of IFM on vertebrate diversity are indirect through habitat modification. Terrestrial vertebrate responses to IFM are species-specific and directly linked to intensity and extent of habitat modification. Shorter crop tree rotations compress successional stages and limit development and recruitment of mature forest structures (e.g., snags, den/roost trees, coarse woody debris). During stand establishment, increased intensification of site preparation and weed control tends to result in lower vertebrate diversity. Generally, vertebrate
\end{abstract}




\section{DRAFT Terrestrial Vertebrate Biodiversity and IFM in the U S}

diversity of IFM stands is reduced after stand establishment until canopy closure as sunlight to the forest floor is progressively restricted, reducing vegetation structural complexity. However, intermediate management practices like thinning, which re-opens the forest canopy, generally elicit positive or neutral effects on most vertebrate taxa. Final tree harvest removes the overstory and, predictably, vertebrate taxa depending on older or undisturbed forest conditions decline and early seral species increase. To ameliorate negative effects of final harvest on terrestrial vertebrate diversity, land managers have instituted various practices, including retaining habitat elements, protecting riparian zones and sensitive ecological areas, and limiting final harvest unit size as well as how soon an adjacent forest patch can be harvested. Juxtaposition and interspersion of forest stands of varying ages are important determinants of terrestrial vertebrate responses to intensively managed landscapes. A typical intensively managed landscape contains a variety of stand ages, forest types, and other features (e.g., streams, mature forest stands, setaside areas) that provide habitat for a diversity of terrestrial vertebrate species. Landscape context has direct ramifications for terrestrial vertebrate diversity in intensively managed landscapes, with negative effects more pronounced in forests imbedded in agriculture or anthropogenic landscapes. Most field studies have been of short duration ( $<5$ years) and localized (e.g., multiple stands in an area), hence we call for a greater commitment to longerterm research and monitoring replicated across landscapes. Significant research gaps include how to improve functionality of retained structures, riparian zones, and unique ecological communities, whether vertebrates are evolving or adapting to the rapid changes in habitat conditions characteristic of IFM, and how landscape context, including spatial distribution of varying stand ages, affects vital rates of terrestrial vertebrate species (hereafter wildlife). 


\section{DRAFT Terrestrial Vertebrate Biodiversity and IFM in the U S}

Key Words: biodiversity, intensive forest management, forest thinning, herbicide, stand establishment, terrestrial vertebrates

\section{Introduction}

Forests are globally the most diverse terrestrial ecosystem (Schmitt et al. 2009, FAO 2010, IUCN 2010), and contribute numerous ecosystem services, including wood products, carbon storage, clean water, biodiversity, and pollination (UNEP 2007, FAO 2009). As global demand for wood has increased, intensification of forest management in some locales has also increased (FAO 2009), which can affect the ability of managed forests to support biodiversity (Miller et al. 2009). Reduced levels of dead wood, simplification of forest structure and composition, and constraints on age and size of intensively managed forests (IFM) tend to negatively affect within-stand measures of biodiversity (Stephens and Wagner 2007). However, contributions of IFM to global biodiversity should not be overlooked (Brockerhoff et al. 2008). Those contributions vary depending on particular silvicultural techniques, effectiveness of and compliance with existing laws or voluntary guidelines, and the ecological contexts of these forests (Carnus et al. 2006, Brockerhoff et al. 2008). Descriptions of limitations and contributions of IFM to biodiversity conservation are often confounded by spatial and temporal scales of assessments (Carnus et al. 2006, Brockerhoff et al. 2008).

Growing concerns over effects of biodiversity loss on ecosystem services (Balvanera et al. 2006, Daily et al. 2009, Cardinale et al. 2012) have led to more precise definitions of mechanisms linking biodiversity to ecosystem function. Biodiversity, including the number abundance and composition of genotypes, populations, species, functional types, communities and landscape units, underlies production of ecosystem services, and thus human well-being, 


\section{DRAFT Terrestrial Vertebrate Biodiversity and IFM in the U S}

through increased resilience to a changing environment (Millenium Ecosystem Assessment 2005). Additionally, increasing species diversity has been clearly linked to increased productivity and ecosystem stability with both enhancing the net production of ecosystem services for humans (Balvanera et al. 2006, Millenium Ecosystem Assessment 2005). Although wood production is viewed as an ecosystem service, growing demands for diverse forest resources requires a balance between wood production and conservation of biological diversity (Stephens and Wagner 2007).

Globally, forests ${ }^{1}$ covered approximately 3,999 million ha in 2015, which is about 129 million ha less than in 1990, a change from 31.6 to $30.6 \%$ of global land area (FAO 2015). In the U.S., forest cover has been relatively stable for the last 100 years (Oswalt et al. 2014:2), although forest structure, composition, and management intensity have changed. Forests currently cover about one-third of the United States (310.1 million ha) with an additional 2\% (21.3 million ha) classified as woodlands $^{2}$ (Oswalt et al. 2014:2). Most forestland in the U.S. is privately owned (58\%), with $39 \%$ owned by private, non-corporate entities (e.g., individuals, families, tribes) and $19 \%$ by private corporate entities (Oswalt et al. 2014), many of which are institutional investors. Federal, state, and local governments manage the other $42 \%$ of forestland in the U.S. Wood production is important to many private owners, with $58 \%$ of non-corporate forests owned by people who have commercially harvested trees (Butler 2008). In 2011, 89\% of timber harvested in the U.S. was on private lands (Oswalt et al. 2014: Appendix B, Table 35). To meet societal demands for wood fiber, landowners (particularly institutional forest owners, Arano and Munn

${ }^{1}$ Forests are defined by the U. S. Department of Agriculture Forest Service Inventory and Analysis Program as land with $\geq 10 \%$ cover by trees (Oswalt et al. 2014, page 2). 2 Woodlands are defined by the U. S. Department of Agriculture Forest Service as land with $\geq 5 \%$ and $<10 \%$ cover by trees (Oswalt et al. 2014, page 2 ). 


\section{DRAFT Terrestrial Vertebrate Biodiversity and IFM in the U S}

2006) often employ intensive management to actively ameliorate factors that limit tree growth by manipulating soil and stand conditions thereby enhancing forest growth and return on investment (Van Deusen et al. 2012, Mendell et al. 2015), including reducing rotation lengths. Common practices include mechanical and chemical site preparation, planting selectively improved seedlings, manipulating stand density, controlling competing vegetation, and fertilization (Fox 2000, Allen et al. 2005).

Although not applicable to all regions where some IFM are naturally regenerated, area of planted forests can serve as a coarse proxy for extent of intensive forest management (Fox 2000). In 2015, 7\% of global forests, or 290 million hectares, were planted, accounting for $49 \%$ of global wood production (FAO 2015, Payn et al. 2015). In 2012, an estimated 26.5 million ha ( $8.6 \%$ of total forest land) in the U.S. was planted of which $71.5 \%$ was in the South, $18.5 \%$ occurred in the Pacific Coast region, $9.1 \%$ was in the North, and $<1 \%$ was in the Rocky Mountains (Oswalt et al. 2014: Appendix B, Table 8). In 2012, 50\% of planted forest area in the U.S. was loblolly-shortleaf pine (Pinus. taeda - P. echinata), 11\% longleaf-slash pine $(P$. palustris - P. elliottii), 11\% Douglas-fir (Pseudotsuga menziesii), 6\% oak (Quercus spp.) - pine (Pinus spp.), and 5\% white-red-jack pine (P. strobus-P. resinosa-P. banksiana) (Oswalt et al. 2014: Appendix B, Table 8).

In the U.S., laws, regulations, and non-regulatory guidelines influence environmental effects of IFM. For example, laws such as the Endangered Species Act (16 U.S.C. §1531-1544) and Federal Water Pollution Control Act (33 U.S.C. §1251 et seq.), protect federally designated plant and animal species and the physical, chemical, and biological integrity of waters, respectively. Similarly, states have laws, regulations, and other programs (e.g., State Wildlife Action Plans) that protect endangered species and conserve species and ecosystems. Some states 


\section{DRAFT Terrestrial Vertebrate Biodiversity and IFM in the U S}

also have forest practice acts that dictate how private and public landowners can harvest timber and identify Best Management Practices (BMPs). States without a forest practices act have nonregulatory BMPs that protect water quality and subsequently provide biodiversity benefits (e.g., maintenance of older aged forests along riparian areas, Blinn and Kilgore 2001). Implementation of BMPs is high (>90\%; NASF 2015) regardless of whether the BMPs are regulatory or nonregulatory. Further, BMPs are required for landowners with forest certification (Cite?).

Over the last 20 years, many forest managers also have operated under the auspices of forest certification programs that explicitly include provisions for biodiversity conservation. The three most widely applied certification standards for forest management in the U.S. are the Sustainable Forestry Initiative (SFI), Forest Stewardship Council (FSC), and American Tree Farm System (ATFS). All of these standards require forest managers to address social, ecological, and economic impacts of forest management. Additionally, fiber sourcing standards require organizations that do not own land but procure wood or fiber, like sawmills or pulp mills, to implement practices that will ensure that their wood comes from sources that use forestry BMPs to protect water quality, broaden the practice of biodiversity conservation, provide outreach to landowners, and use the services of trained forest management and harvesting professionals. Although compliance with forest certification standards and accompanying fibersourcing standards is voluntary, large private landowners view participation as necessary to demonstrate sustainability and maintain market access.

In the past two decades, IFM practices have changed regionally (Vance et al. 2010). In the Southeast, where most intensively managed forests in the U.S. occur, management now includes techniques (e.g., thinnings, longer rotations as compared to pulpwood rotations on many acres) that yield multiple forest products and promote more rapid development of greater-value 


\section{DRAFT Terrestrial Vertebrate Biodiversity and IFM in the U S}

products (i.e., sawtimber). In Douglas-fir forests of the Pacific Northwest, there is increasing use of genetic tree improvement, chemical site preparation, shorter rotations, and stocking control. In the Northeast, many naturally generated forests dominated by spruce (Abies spp.) and/or fir (Picea spp.) are treated with herbicides, thinned precommercially and commercially, and clearcut (Maine Forest Service 2014) and thus may be considered IFM. IFM in the Upper Midwest includes conifer plantations. As in other regions, improved genotypes from tree breeding (for productivity and pest/disease resistance), more intensive site preparation, and fertilization are common practices. Furthermore, area of managed forests and volume of wood sourced under certification programs have substantially increased. Changes in forest management regimes over the past 20-25 years and increased participation in forest certification programs warrants an assessment of biodiversity contributions from IFM in the U.S.

Given the extent of IFM in the U.S., their known and potential effects on biological diversity, and the need for managers to have access to current information about intensive forest management and biodiversity, our objective was to review and summarize the scientific literature on contributions of IFM to vertebrate biodiversity. We emphasized research on vertebrate diversity in the U.S. and Canada that has emerged in the past two decades. Vertebrate diversity is one aspect of biodiversity studied in IFM that particularly resonates with land managers. Additionally, the vast majority of research has focused on terrestrial vertebrate species. We acknowledge the significant ecosystem services and importance of invertebrate species (Werner and Raffa 2000, Root et al. 2016), but this is outside the purview of our current effort. We organized our review according to the typical sequence of management activities associated with IFM: stand establishment following timber harvest; intermediate-aged treatments like thinning and pruning; and factors associated with final harvests, including streamside management zones 


\section{DRAFT Terrestrial Vertebrate Biodiversity and IFM in the U S}

(SMZs; also known as riparian management zones) and protection of other inoperable areas. We conclude our review with landscape-scale considerations and suggest management recommendations and future research needs.

\section{Methods}

Our literature review emphasized studies conducted over the last 25 years on IFM in the United States, but we incorporated studies dating back to 1960 to supplement the more recent literature as needed to fill research gaps. We structured our review according to typical forest development stages of IFM, emphasizing silvicultural techniques associated with stand establishment, intermediate treatments, and final harvest. Hereafter, a stand refers to a management unit of a relatively homogenous patch of trees identified for specific forest management objectives. Intensive forest management generally involves even-aged management where each stand is treated as a management unit of same aged trees. We used systematic online searches of electronic databases that included Google Scholar, EBSCOhost, JSTOR, Proquest, and Web of Science. Our searches used a variety of terms including biodiversity, habitat, niche, and taxonomic groups that were known to occur in IFM, particularly looking for studies that quantified direct and indirect effects. We also searched on silvicultural practices (e.g., site preparation, planting, forest chemicals, herbicide application, thinning, prescribed burning) typically used on IFM. We note that literature reviews exist measuring wildlife response to some treatments commonly associated with intensive forest management (deMaynadier and Hunter 1995, Russell et al. 2004, Zwolak et al 2009, Riffell et al 2011; Verschuyl et al. 2011, Cristan et al. 2016, and others). However, many of the treatments associated with IFM are relatively new, and thus so is the body of literature. Aside from adding a wealth of contemporary literature, we provide a comprehensive review of terrestrial vertebrate responses to the compilation of 


\section{DRAFT Terrestrial Vertebrate Biodiversity and IFM in the U S}

treatments associated with IFM. Although our focus was on IFM, we also incorporated research from some less intensively managed forests that provided relevant results on terrestrial vertebrate responses to individual management practices, and to a lesser extent, we used literature from outside the U.S. (primarily Canada) to inform our results.

\section{Stand Establishment}

Depending on site and market conditions, silvicultural treatments used to establish IFM include site preparation, weed control, and planting of high-quality seedlings (Allen et al. 2005). On some sites, competing vegetation also may be suppressed temporarily from herbicide use. Stand establishment is analogous to the stand initiation phase of natural stand development described by Oliver and Larson (1996).

\subsection{Site preparation}

Within a year of final harvest, stands are either allowed to naturally regenerate or are prepared for planting of selectively-improved tree seedlings using mechanical or chemical techniques alone or in combination. The ultimate goal of site preparation is to create a suitable growing environment that results in rapid reforestation. Vertebrate biodiversity response to stand establishment practices is strongly influenced by intensity of site preparation (e.g., White et al. 1976; Johnson and Landers 2015; Enge and Marion 1986; Haeussler et al. 1999; Lane et al. 2011; Miller and Miller 2004; Jones et al. 2009a, 2010; Iglay et al. 2012b, Greene et al. 2016), where intensity is typically described by the amount of exposed mineral soil, extent and intensity of vegetation suppression, or the type of site preparation (chemical, mechanical, both). Generally, increased intensification results in reduced levels of vertebrate diversity.

\subsubsection{Mechanical site preparation}




\section{DRAFT Terrestrial Vertebrate Biodiversity and IFM in the U S}

Mechanical site preparation (MSP) prepares planting substrates and temporarily suppresses competing vegetation. Mechanical site preparation influences soil depth, structure, strength, and aeration; influences water availability for seedlings; reduces or moves woody debris to facilitate planting; and reduces fire hazard (Lowery and Gjerstad 1991, Allen et al. 2005). Mechanical site preparation can be conducted via chopping, burning, shearing, windrowing, root-raking, and bedding (Fox et al. 2007). However, in stands with established hardwood vegetation, MSP alone may not effectively control hardwood sprouts (Fox et al. 2007). Mechanical site preparation can result in loss of snags and downed wood that were retained during timber harvest (Lane et al. 2011, Swift and Bell 2011, Hanberry et al. 2012a, Loman et al. 2013), with negative consequences for vertebrates associated with these features. However, MSP is positively correlated with vegetation nutrition, cover, richness and diversity within 1-2 years of tree planting (Stransky and Halls 1976, Conde et al. 1983, Swindel et al. 1983, Stransky et al. 1986, Pearson et al. 1995, Campbell et al. 2015); this effect persisted until crown closure but had minimal effect on wildlife habitat quality (Campbell et al. 2015).

Vertebrate responses to MSP depend on direct effects caused by mechanized equipment and soil disturbance (Newmaster et al. 2007, Wester and Kolb 2008, Smith et al. 2015), and indirect effects caused by changes to plant community composition, abundance, and structure (Newmaster et al. 2007). Direct mortality from logging equipment can be relatively high for small mammals (e.g., 52\% of marked individuals; Escobar et al. 2015 [Chile]). Intensity of MSP, which is defined by amount of exposed mineral soil, can be negatively correlated with plant abundance, may promote non-native species (Haeussler et al. 1999, Lane et al. 2011, Newmaster et al. 2007, Lane et al. 2011), and has resulted in fewer wintering birds (Hanberry et al. 2013). Additionally, intensive MSP reduced availability of ground litter to vertebrate species 


\section{DRAFT Terrestrial Vertebrate Biodiversity and IFM in the U S}

(Greenberg et al. 1994). For example, abundance of five-lined skinks (Eumeces inexpectatus) was lower on mechanically treated plots as compared to mature forest plots in southeast sand pine (P. clausa) scrub (Greenberg et al. 1994). However, Russell et al. (2002) reported no differences in overall richness, abundance, or community similarity of amphibian and reptile communities at wetlands where surrounding 18- to 25-year-old loblolly pine stands were clearcut and treated with MSP. Negative impacts of MSP on more mobile vertebrate species, such as birds, were absent in southern pine plantations (Kilgo et al. 2000).

\subsubsection{Chemical site preparation}

Site preparation on most upland stands now relies on selective herbicides to temporarily suppress vegetation competing with commercial tree species prior to planting (Lowery and Gjerstad 1991, Fox et al. 2007). On institutional forest ownerships, herbicides for site preparation are most often broadcast using a helicopter or ground-based machine (Weatherford et al. 2015), with effects on biodiversity depending on spatial coverage and effects on vegetation. Because individual chemicals are used to target specific plant species, vegetation competition and structure vary by herbicide type or herbicide mixes and the existing plant community (Miller and Miller 2004, Iglay et al. 2010, Solecki et al. 2014).

Similar to MSP, vertebrate responses to chemical site preparation (CSP) are affected by intensity of chemical application, which vary by chemical and extent of application (e.g., broadcast more intense than banded; Lane et al. 2011, Jones et al. 2012b). Applications that result in greater suppression of vegetation negatively affect vertebrate diversity in the short-term by simplifying live vegetation structure (Jones et al. 2012a). In the southeastern U.S., CSP reduced live tree density and increased snag density relative to mechanical methods (Neu et al. 2014). Retention of habitat elements such as snags and small green trees can enhance vertebrate 


\section{DRAFT Terrestrial Vertebrate Biodiversity and IFM in the U S}

biodiversity in stands chemically prepared for planting (e.g., birds, O’Connell and Miller 1994, Hanberry et al. 2012a). Short-term negative effects of CSP on abundance of herbaceous plant species are well-documented (Harrington et al. 1998, Lauer and Zutter 2001, Miller and Chamberlain 2008).

Vertebrate responses to CSP are taxon specific. Herpetofauna occurred at low abundances in stands with more intense CSP compared to less intensely treated stands (Enge and Marion 1986), and aquatic larval stages may be particularly sensitive (Swift and Bell 2011). Generalist small mammals like Permoyscus spp. were more resilient to intense CSP, whereas species with affinities for herbaceous vegetation tended to decline (Harris et al. 1974, White et

al. 1976, Lane et al. 2011), likely due to reduced coverage of grasses and forbs (White et al. 1976) which affect escape cover, food resources, and thermoregulatory opportunities. Birds have exhibited resilient responses to CSP throughout North America (e.g., Sullivan and Sullivan 1982; Morrison and Meslow 1984a, 1984b; Runciman and Sullivan 1996; Kilgo et al. 2000; Lane et al. 2011; Betts et al. 2013). For example, birds in western Oregon switched their foraging substrate from shrubs to deciduous trees after a CSP that targeted shrubs (Morrison and Meslow 1984a), and total bird density in treated and untreated clearcuts did not differ (Morrison and Meslow 1984b). Relatively low amounts of broadleaf cover $(<5 \%)$ can maintain some avian species in young regenerating stands in the Oregon Coast Range (Betts et al. 2010, Ellis and Betts 2011). When herbicides targeted broadleaf vegetation, abundance of leaf-gleaning early seral bird species was reduced (Betts et al. 2013). Practices that retain some deciduous vegetation while simultaneously regenerating conifer cover appear to positively influence bird communities (Jones et al. 2012a). Hanberry et al. (2013) found that wintering bird abundance in Mississippi was greatest in chemically treated pine sites for the first 5 years. 


\section{DRAFT Terrestrial Vertebrate Biodiversity and IFM in the U S}

Beyond 5 years, differences between stands with and without CSP are generally minimal for small mammals and birds (O’Connell and Miller 1994, Brooks et al. 2001). In some instances, bird diversity can increase on sites treated with CSP (Brooks et al. 2001). For whitetailed deer (Odocoileus virginianus), CSP is a useful technique for maintaining high quality deer forage within intensively managed pine stands in the southeastern U.S. (Chamberlain and Miller 2006, Jones et al. 2009a).

\subsubsection{Mechanical and chemical site preparation}

In some situations, forest managers may prescribe both MSP and CSP. Mechanical techniques disperse logging slash and expose mineral soil, with chemicals as a follow-up for temporary suppression of competing vegetation. This combination of practices, particularly multiple broadcast applications for herbaceous weed control (which are infrequently used), results in a more intense effect (Jones et al. 2009a). Indeed, this combination resulted in plant communities that did not provide sufficient high quality forage for lactating white-tailed deer, although vegetation abundance was adequate for maintenance of non-lactating white-tailed deer (Jones et al. 2009a).

Forest managers may also have the option to choose between mechanical or chemical site preparation. Small mammal capture rates were highest in stands that were mechanically treated compared to chemically treated 2 years after treatment in southeastern pine (O'Connell and Miller 1994). In contrast, bird species richness and abundance were $1.5-4$ times greater in chemically treated stands in the southeastern U.S., but these effects were likely due to green tree and snag retention in treated stands (Lane et al. 2011, Hanberry et al. 2012a, 2012b). Similarly, Greene et al. (2016) found that birds and open pine wildlife species responded more favorably to CSP compared to MSP. Plant species composition and the successional trajectory of plant 


\section{DRAFT Terrestrial Vertebrate Biodiversity and IFM in the U S}

communities were more significantly altered in chemically-treated pine stands in Louisiana, compared to mechanically-treated stands (Miller and Chamberlain 2008). In Mississippi, chemically prepared stands provided opportunity for greater expression of early succession herbaceous and subshrub communities relative to stands mechanically prepared (Jones et al. 2012b). However, pine canopy closure might occur more quickly in chemically treated stands (Miller and Chamberlain 2008) limiting the value for many species to fewer years.

\subsubsection{Manual practices and prescribed fire}

Manual removal of competing trees during site preparation can provide a positive effect on vertebrates within IFM ecosystems (Harrington and Edwards 1996, Lindgren and Sullivan 2001). Vertebrates indirectly benefitted from tree removal with chainsaws as compared to large machinery. Tree diversity was greater in chainsaw removal stands, which provided a greater variety of residual trees for vertebrates in the Georgia Piedmont (Harrington and Edwards 1996).

Studies on burning as a site preparation technique (Carter and Foster 2004) have shown different effects on vertebrate and vegetation abundance within IFM (Brender and Cooper 1968, Stransky and Halls 1976, Buckner and Landers 1979, Scanlon and Sharik 1986, Hurst et al. 1994, Harrington et al. 1998). In comparison to MSP and CSP, burned stands had lesser abundances of woody species (Buckner and Landers 1979, Harrington et al. 1998). Prescribed burning also reduced density of CWD and density and volume of piled CWD compared to chemical and mechanical methods (Neu et al. 2014). Burning tends to temporarily reduce structural complexity for vertebrates that rely on woody understory vegetation and CWD, potentially resulting in negative impacts to terrestrial amphibians, shrub nesting birds, and generalist small mammals. However, burning can substantially increase amount of herbaceous vegetation (Brender and Cooper 1968), favoring vertebrates that rely on dense herbaceous 


\section{DRAFT Terrestrial Vertebrate Biodiversity and IFM in the U S}

vegetation. Burning can also have substantial positive effects on plant nutrient content that directly affects quality of vertebrate forage (Stransky and Halls 1976).

\subsection{Herbaceous weed control}

After tree planting, some managers temporarily suppress herbaceous weeds using chemicals (Shepard et al. 2004, Lang et al. 2016). On institutional forest lands, herbicides for herbaceous weed control (HWC) are typically applied using broadcast (helicopters) or in bands along rows of planted trees (backpack sprayer or ground-based machinery) and rarely are applied in two sequential years (Weatherford et al. 2015). However, prescriptions differ widely based on site conditions and forest management objectives. Variation in vertebrate response to HWC depends on the species, application technique, chemical(s) used, and frequency of application (Lane et al. 2011).

Vertebrate responses to HWC are complex, vary by taxa, chemicals used, application methods, and other factors. Herbaceous weed control alters composition and abundance of herbaceous plant communities and temporarily reduces plant diversity (Blake et al. 1987, Zutter and Zedaker 1988, Swindel et al. 1989, Miller and Miller 2004). For example, HWC reduced non-pine cover in 5-year-old stands from 100\% to $10 \%$ in Florida, USA (Swindel et al. 1989). At five years post-treatment, pine cover made up $73 \%$ of the canopy on treated plots, but only $11 \%$ of the canopy on control plots (Swindel et al. 1989). In this example, two factors had potential negative consequences for vertebrate diversity: 1) vertical simplification of vegetation structure and diversity in regenerating stands, and 2) shortening time to the stem exclusion phase of plantation development. Herbaceous weed control facilitates expression of herbaceous and subshrub plant communities, increasing variability in plant species turnover as the stand develops (Jones et al. 2012b). Broadcast application of chemicals for HWC is typically viewed as more 


\section{DRAFT Terrestrial Vertebrate Biodiversity and IFM in the U S}

intense, potentially resulting in greater negative plant and terrestrial vertebrate effects. However, Jones et al. (2012b) found that a single broadcast application did not prevent strong reemergence of the herbaceous and sub-shrub plant community the following year in Mississippi. Only multiple broadcast applications extended control of early seral conditions beyond the year of final treatment (Jones et al. 2012b).

Herbicides targeting herbaceous vegetation in young stands tended to favor small mammal species with affinities for woody or shrubby vegetation conditions [where?] (e.g., Borrecco et al. 1972, 1979; Savidge 1978; Anthony and Morrison 1985). Coarse measures of avian community response (e.g., species diversity, overall density) have often shown nonsignificant or positive responses to herbicide applications, but species-specific responses have varied substantially (Morrison and Meslow 1984a, 1984b; Santillo et al. 1989a, 1989b; Brunjes et al. 2003). Others have reported no strong correlation between HWC and measures of vertebrate and habitat diversity (Boyd et al. 1995; Guynn et al. 2004; Sullivan 1996; Sullivan et al. 1998a, 1998b; Wagner et al. 2004).

Herbaceous weed control, particularly broadcast applications of herbicide, has been found to reduce abundance of white-tailed deer forage (Blake et al. 1987). Herbicides have not been found to repel ungulates from foraging on treated browse (Sullivan and Sullivan 1979, Campbell et al. 1981) or alter forage digestibility (Newton and Norris 1968, Thilenius and Brown 1976). Chemically treated seedlings, however, were accepted at a lesser rate by blacktailed deer (O. hemionus), presumably because treated seedlings were less palatable (Campbell et al. 1981). Proportion of digestible dry matter available to herbivores increased after HWC because of greater grass biomass in subalpine forests of Wyoming (Thilenius and Brown 1976). Jones et al. (2009a) and Lane (2010) suggested that to both expedite pine growth and provide 


\section{DRAFT Terrestrial Vertebrate Biodiversity and IFM in the U S}

habitat conditions important to vertebrates in the southeastern U.S., banded HWC provided the best option.

\subsection{Duration of early seral conditions}

Site preparation, planting of selectively improved seedlings, and HWC results in prompt reforestation and rapid forest development. In most cases, measures of plant cover and species richness indicate relatively rapid (i.e., 3-5 years) recovery of the plant community after mechanical or chemical applications (Beaver 1976, Morrison and Meslow 1984a, Anthony and Morrison 1985, Sullivan 1996, Rice et al. 1997, Cole et al. 1998, Jones et al. 2012b). This stand initiation phase of forest development tends to be plant species-rich and can provide appropriate habitat conditions for early seral vertebrate species (e.g., Miller and Chamberlain 2008 Swanson et al. 2011, Umber and Harris 1971). Intensive forest management, however, accelerates forest development to the stem exclusion phase (sensu Glenn-Lewin et al. 1992:269, Oliver and Larson 1996; as demonstrated by Jones et al. 2012b), during which early seral plant communities and associated vertebrate species are diminished (e.g., northern bobwhite (Colinus virginianus); Jones et al. 2010). These consequences have caused some observers to advocate for planning landscape-level management activities so that a variety of forest successional stages are available for vertebrates (Oliver and Larson 1996). Such landscape diversity generally occurs on managed forest landscapes from stand-level, even-aged management strategies with adjacency restraints (Miller et al. 2009).

\section{Intermediate treatments}

\subsection{Thinning}




\section{DRAFT Terrestrial Vertebrate Biodiversity and IFM in the U S}

Silvicultural thinning methods differ with ownership and region. Contemporary forest thinning treatments on public lands, particularly in the western U.S., are most commonly an element of ecological forestry (Franklin and Johnson 2012), management guided by forest health concerns (e.g. Mainwaring et al. 2005) or are part of fire fuels management (Agee and Skinner 2005, USDA Forest Service 2005). On private ownerships, and particularly in the southeastern U.S., thinning is a standard practice in most intensively managed pine stands (Homyack et al. 2011; Lindgren and Sullivan 2013) and, in many cases, a second thinning is applied (Lang et al. 2016). Similarly, red pine (P. resinosa) plantations are thinned in northern states to encourage residual tree growth and to retain the highest value trees.

Thinning is occurs in three broad categories: pre-commercial, commercial, and fuels treatment. Pre-commercial thinning (PCT) reduces density of young trees in a stand, often near the time of stem-exclusion, to release crop trees from competition and increase growth. The value of material removed in PCT operations typically does not exceed cost of operations. Precommercial thinning is as a way to increase volume at rotation age by eliminating the period of self-thinning or competitive exclusion (Reukema 1975).

Commercial thinning is a partial-cutting process, common in intensively managed forests of the Southeast and North, which produces merchantable wood products at least equal to the value of harvesting costs (Helms 1998). Similar to PCT, a commercial thin often attempts to retain the largest, most vigorous trees (called crop trees) and removes others. Fuels treatment thinning removes understory vegetation to reduce risk of uncharacteristically large and intense wildfire and is an important part of some forest management regimes in dry forests of the interior western U.S. (Gaines et al. 2010, Lehmkuhl et al. 2015). Fuels treatment thinning is used for 


\section{DRAFT Terrestrial Vertebrate Biodiversity and IFM in the U S}

restoration and forest health, and is not generally considered a component of intensive forest management.

Verschuyl et al. (2011) used meta-analyses to examine thinning and vertebrate biodiversity based on 505 effect sizes from 33 studies in North America. They found that forest thinning generally had positive or neutral effects on diversity and abundance across all taxa, although thinning intensity and type determined magnitude of responses. Birds, small mammals, reptiles and bats responded positively to thinning. Greene et al. (2016) also found positive response by reptiles and small mammals. Similarly, a trait-based approach to ecosystem assessment indicated that thinning was positively related to food availability for wildlife, and increased the cover of drought-, fire-, and heat tolerant plant species found in managed Douglasfir of Oregon (Neill and Puettmann 2013). However, there was overall neutral response by amphibians and negative responses from a few disturbance sensitive species (Verschuyl et al. 2011).

Across North America, bird responses to thinning treatments of all types are speciesspecific, with non-significant treatment effects on species richness and diversity measures (Verschuyl et al. 2011). Additionally, avian abundances, including species of conservation concern and game species, tend to be maintained after thinning (Dellasala et al.1996, Dickson 2001, Hurst and Warren 1982, Iglay 2010, Miller and Conner 2007, Smith et al. 1990, Burger 2001, Jones and Chamberlain 2004). A notable exception is Swainson's warbler (Limnothlypis swainsonii), a species of high conservation concern, that occurs in closed canopy, unthinned, intensively managed forests in the southeastern U.S. (Bassett-Touchell and Stouffer 2006, Graves 2014, Henry et al. 2015), that is negatively affected by thinning (Bassett-Touchell and Souffer 2006, Verschuyl et al. 2011). 


\section{DRAFT Terrestrial Vertebrate Biodiversity and IFM in the $\mathbf{U} \mathbf{S}$}

\subsubsection{Precommercial thinning}

Studies of vertebrate response to PCT have primarily addressed small mammals. Precommercial thinning increased abundance of forest floor-dwelling small mammals in young Douglas-fir forests on the Oregon coast (Suzuki and Hayes 2003). In dense lodgepole pine (Pinus contorta) in British Columbia, Canada, moderate levels of PCT can open the canopy and favor occupancy of arboreal rodents such as northern flying squirrel (Glaucomys sabrinus) and red squirrel (Tamiasciurus hudsonicus) (Ransome et al. 2004). Similarly, PCT in Maine increased abundances of small mammals associated with mid-seral forest conditions (Homyack et al. 2005). Negative responses to PCT have been shown in the first two years after treatment for specialist species like snowshoe hare (Lepus americanus) that depend on high levels of vegetation cover (Griffin and Mills 2007, Ivan et al. 2014). However, effects of PCT on snowshoe hares may be ephemeral, with no response evident 10-15 years post-harvest (Sullivan et al. 2007). Additionally, PCT appears to consistently cause a reduction in snowshoe hare abundance,. However population vital rates were not impacted in an Oregon study (Abele et al. 2013). In Maine, PCT reduced snowshoe hare densities by approximately half compared to unthinned stands at least 11 years post-treatment (Homyack et al. 2007). Also in Maine, PCT reduced understory structure and complexity, potentially having a negative effect on species dependent on early successional vegetation conditions, but may positively affect vertebrate species that use more mature forests (Homyack et al. 2004). Some concerns over effects of PCT on fruit-bearing plants exist, but research in Quebec, Canada, suggested that effects were negligible (Major and Desrochers 2013).

\subsubsection{Commercial thinning}




\section{DRAFT Terrestrial Vertebrate Biodiversity and IFM in the U S}

Managers have wide discretion in target basal area after commercial thinning(s) with decisions primarily based on economic return and wood product objectives. Thinning treatments that retain less basal area allow more light penetration to the ground for more years, indirectly promoting vertebrate biodiversity through growth of herbaceous and shrubby vegetation. In southern pine forests, the resultant stand structure, a tree overstory with canopy gaps and a primarily herbaceous understory, emulates stand conditions that were historically maintained by fire (Brennan et al. 1998, Iglay 2010, Singleton et al. 2013, Iglay et al. 2014b, Greene et al. 2016).

In contrast to the generally neutral effects of thinning on birds observed across North America (Verschuyl et al., 2011), avian diversity in southern pine (Karriker 1996, Wilson and Watts 1999, 2000), and lodgepole pine forests (Bayne and Nielsen 2011), appears to positively correlate with thinning. Bayne and Nielsen (2011) note that their results were consistent with $83 \%$ of thinning studies conducted in western coniferous forests. In North Carolina, brownheaded nuthatches (Sitta pusilla), a species of conservation concern (http://www.partnersinflight.org/WatchListNeeds/BHNU.htm, accessed 5 August 2016), reached their highest abundance one year after thinning (none detected prior to thinning) and then declined in subsequent years (Wilson and Watts 1999). Brown-headed nuthatch abundance was associated with snags, suggesting that creation and retention of snags during thinning operations was important. Post-thinning declines of brown-headed nuthatches were correlated with development of dense midstory vegetation (Wilson and Watts 1999). Snag importance was further emphasized in thinned pine forests in North Carolina, where 53 bird species were detected, including 9 cavity-nesters (Homyack et al. 2011). Similarly, northern spotted owls (Strix occidentalis caurina) increased use of stands that were thinned in southern Oregon and 


\section{DRAFT Terrestrial Vertebrate Biodiversity and IFM in the U S}

northern California (Irwin et al. 2015), potentially because prey was more abundant and accessible. In thinned mixed conifer stands in the Sierra Nevada, canopy, cavity and shrubnesting bird species were found in greater abundances (Siegel and DeSante 2003), and small mammal species richness and abundance were greater or unchanged (Hood et al. 2002, Amacher et al. 2008, Wampler et al. 2008) compared to unthinned stands.

Numerous studies have reported positive effects of thinning on small mammals (Garman 2001, Zwolak 2009, Iglay 2010, Sullivan et al. 2013). Small mammals in streamside management zones (SMZs) in Arkansas were strongly influenced by structure of surrounding IFM, with SMZs adjacent to young, open and thinned plantations having greater species richness and abundance than those adjacent to closed canopy plantations (Miller et al. 2004). In North Carolina, thinned plantations had dissimilar small mammal communities as compared to undisturbed pocosins, with differences due to presence of pioneering species in young, open and thinned plantations (Mitchell et al. 1995). Thinning in mature Douglas fir forests in the Oregon Cascades reduced northern flying squirrel abundance 11-13 years after treatment, with thinning intensity negatively correlated with flying squirrel density (Manning et al. 2012). Similarly, thinning reduced abundance of snowshoe hares for 11-18 years in Quebec, Canada, before vegetation and hares recovered (Bois et al. 2012), and use by spruce grouse (Falcipennis canadensis) was also reduced (Lycke et al. 2011). For white-tailed deer, thinning increased forage production in the southeastern U.S. (Blair 1960, Conroy et al. 1982, Hurst and Warren 1982). Additionally, herbicide use to reduce midstory hardwoods and prescribed fire further improved browse conditions (Hurst and Warren 1982, Edwards et al. 2004, Jones et al. 2009, Iglay et al. 2010). 


\section{DRAFT Terrestrial Vertebrate Biodiversity and IFM in the U S}

Thinning is largely viewed as positive for bats, as it reduces forest obstructions thus increasing suitability for foraging, commuting (Loeb and Waldrop 2008, Bender et al. 2015), and roosting (Elmore et al. 2004, Miles et al. 2006). Red bats (Lasiurus borealis) occupying an IFM landscape in Mississippi sought roost sites with denser canopy in thinned stands compared to unthinned stands (Elmore et al 2004). Bats in Georgia chose roosting sites based on proximity to valuable habitat resources in unmanaged stands, while bats in intensively managed stands were more likely to choose roosts based on tree and plot characteristics (Miles et al. 2006). In Arkansas, USA bat species were more likely to roost in landscapes containing an abundance of thinned forest stands (Perry et al. 2008). Bats used edges between thinned stands and young pine stands for foraging and commuting in North Carolina, USA (Morris et al. 2010, KalcounisRueppell et al. 2013).

Few studies have specifically examined responses of reptiles and amphibians to thinning in IFM, with research indicating that thinning effects are generally positive or neutral (Grialou et al. 2000, Jones and Dorr 2004, Humphries 2005, Iglay et al. 2014a). In North Carolina, spotted turtles (Clemmys guttata) selected older forests with high canopy closure within intensively managed pine landscapes (O'Bryan et al. 2016); these older forests were largely thinned pine stands. Reptile and amphibian species in Mississippi had greater abundances in thinned loblolly pine stands as compared to younger stands (Jones et al. 2016). The authors speculated that olderaged forest structure (more leaf litter, decay of downed logs, canopy closure) of thinned stands affected those observed responses. While amphibian body condition appeared to be negatively impacted by thinning, there was no significant difference in amphibian abundance in thinned and unthinned forests of northern California (Karraker and Welsh 2006). Thinning elicited positive responses for reptiles and small mammals in southeastern forests, but effects of prescribed fire 


\section{DRAFT Terrestrial Vertebrate Biodiversity and IFM in the U S}

and herbicides after thinning varied by taxa with increases in avian diversity and decreases in amphibian and invertebrate diversity (Greene et al. 2016). Spatial variation in treatment intensity, with attention to microclimate refugia, may aid less mobile species susceptible to the disturbance of the treatment itself (Olson and Rugger 2007).

\subsection{Pruning}

Pruning is sometimes applied after thinning in IFM to increase amount of knot-free wood (Smith 1954, DeBell et al. 1997, Baker and Hunter 2002), and to control blister rust in species such as western white pine (P. monticola) and sugar pine (P. lambertiana) (DeBell et al. 1997). Pruning can enhance structural complexity of the plant community (Baker and Hunter 2002, Zobrist and Hinckley 2005), increase and prolong availability of understory vegetation (Hurst and Warren 1982, Baker and Hunter 2002), and create horizontal canopy openings (Zobrist et al. 2005) that increase amount of sunlight reaching the forest floor (DeBell et al. 1997).

Vertebrate biodiversity response to pruning has not been widely studied in IFM. However, early pruning, in combination with thinning, has been found to create more space beneath the forest canopy for birds and bats to fly, and may enhance the ability of younger forests to serve as connectors to older, more structurally diverse forests (Zobrist and Hinckley 2005). In Arkansas, nest predators and nest predation of birds increased in thinned and pruned loblolly pine forests (19-23 years old) compared to regenerating (3-6 years old) and midrotation (12-15 years old) loblolly pine forests, single-tree selection shortleaf pine forests, and late-rotation shortleaf pine-hardwood forests (Barber et al. 2001). In contrast, diversity and abundance of breeding birds were greater in two Arkansas watersheds dominated by intensively managed loblolly forests, many of which were thinned and pruned, compared to two watersheds dominated by less intensively managed or unmanaged forest stands (Tappe et al. 2004). Active 


\section{DRAFT Terrestrial Vertebrate Biodiversity and IFM in the U S}

management in the intensively managed watersheds provided greater habitat diversity that promoted diversity of the avian community (Tappe et al. 2004). Based on research in the same four watersheds, Loehle et al. (2005b) reported similar results for reptiles, amphibians, and both groups combined, and Kroll et al. (2014) recommended prescriptions that resulted in broad distribution of heterogeneous structural conditions to maintain diverse breeding bird assemblages.

\subsection{Biomass feedstock production}

Increased interest in biofuel production from forests has led to experimentation in the Southeast with intercropping of native prairie grasses (primarily switchgrass (Panicum virgatum)) to produce herbaceous biomass feedstock (Riffell et al. 2012). In intercropping systems, herbaceous plants are seeded between rows of planted trees and then grown and harvested annually (or semiannually) until shade from crop trees excludes the herbaceous crops. Wider tree spacings (often $6.1 \mathrm{~m}$ ) provide sunlight to biofuel crops and facilitate access by harvest machinery (Riffell et al. 2012).

Potential negative implications of intercropping for vertebrates include removal of woody debris during site preparation-covered in greater depth below--(Riffell et al. 2012), replacement of a more diverse understory by a planted monotypical understory (Iglay et al. 2012a, Loman et al. 2014), and more frequent forest disturbance due to annual or bi-annual harvest of grass. Grassland bird use of pure switchgrass patches in a forest matrix was minimal (Marshall 2016). Although researchers speculated that wider tree rows in intercropping forest systems would benefit terrestrial vertebrates because it delays the time until overstory canopy closure, these benefits may be offset by potential within-stand edge effects and disturbances associated with switchgrass harvest (Riffell et al. 2012). 


\section{DRAFT Terrestrial Vertebrate Biodiversity and IFM in the U S}

Intercropping increased coverage and species richness of forbs and non-switchgrass grass species and decreased woody plant coverage compared to non-intercropped forests of the same age (Iglay et al. 2012a). Researchers concluded that intercropping promoted a diverse, herbaceous plant community, but cautioned that longer-term studies are needed (Iglay et al. 2012a). Plant species diversity, non-pine tree biomass, and biomass of white-tailed deer forage was reduced in intercropped stands after switchgrass establishment, but these effects were no longer apparent 2 years after establishment, except that less white-tailed deer browse and total forage was found in the intercropped beds (Wheat 2015).

Biomass removal or switchgrass establishment did not affect detection, diversity, or relative abundance of 15 species of amphibians and reptiles within 2 years post-establishment, despite removal of CWD (Homyack et al. 2013). However, site preparation for switchgrass intercropping, compared to standard site preparation for pine plantations, influenced volume and dispersion of CWD (Loman et al. 2013). Intercropped forests had fewer retained trees and snags than non-intercropped stands, likely having a negative effect on vertebrate species requiring snags (Loman et al. 2013). Neotropical migrants and forest-edge associated species were less abundant in intercropped stands for the first 2 years after establishment and more abundant by year 3 (Loman et al. 2014). Vertebrate species associated with pine-grasslands were less abundant initially but converged with control plots (standard pine silviculture) in subsequent years (Marshall 2016).

White-footed mice (Peromyscus leucopus) did not change diet or trophic position within intercropped and non-intercropped pine forests, indicating that this species maintained functional roles in a novel environment (Briones et al. 2013). As part of the same study, Homyack et al. (2014a) found that, over a 4-year period, natural succession in intercropped forests appeared to 


\section{DRAFT Terrestrial Vertebrate Biodiversity and IFM in the U S}

exert greater influence on rodent communities than intercropping. Conversely, in Mississippi, intercropping reduced rodent community evenness and diversity as compared to nonintercropped forests, due to high abundance of hispid cotton rats (Sigmodon hispidus) in intercropped forests; survival and recruitment of cotton rats did not differ between forest types (King et al. 2014). Larsen et al. (2016) concluded that intercropping switchgrass in loblolly pine stands had minimal effects on rodent communities.

\section{Final Harvest}

Final harvest of mature timber has the potential to limit vertebrate populations requiring older or undisturbed forest structure (Kendrick et al. 2015, Powell and Babbitt 2015). However, forests are most biodiverse at the extremes of their successional gradients, ranging from older forests that have developed complex structure (Lindenmayer and Franklin 2002, Lindenmayer et al. 2006) to young forests prior to tree canopy closure (Duguay et al. 2000, Fuller et al. 2004). In some situations, final harvest is required to perpetuate certain timber types (e.g., aspen [Populus spp.], jack pine), particularly in landscapes where dominant historical disturbances are no longer socially or politically acceptable (e.g., King and Schlossberg 2013, McShea et al. 2015).

\subsection{Clearcutting}

Final harvest in IFM is usually conducted using clearcutting that removes all merchantable trees in one operation (Helms 1998). For mobile organisms like birds, responses to clearcutting are highly variable (Duguay et al. 2000, Gram et al. 2003, Baker and Lacki 1997), but, predictably, abundance of mature forest species has been shown to decline in the near term with a concomitant increase of early successional species (Baker and Lacki 1997, Gram et al. 2003). However, these responses depend on species' life history, clearcut size, surrounding landscape context, and the regional species pool. For example, in the Missouri Ozarks, Brito- 


\section{DRAFT Terrestrial Vertebrate Biodiversity and IFM in the U S}

Aguilar (2005) found a positive relationship between clearcut size (up to 10 ha) and avian species richness. Larger harvest patches may decrease nest predation and brood parasitism (Gustafson and Crow 1994). Kentucky warblers (Geothlypis formosa) and worm-eating warblers (Helmitheros vermivorum) both increased in abundance in clearcut, thinned, and selectively harvested stands in the Missouri Ozarks (Gram et al. 2003). However, clearcuts negatively affected ovenbird (Seirus aurocapilla) density and abundance (Gram et al. 2003). In West Virginia hardwoods, daily nest survival of birds was greatest in unharvested plots, and invertebrate biomass was greatest in the untreated and two-age treatment while clearcuts had lowest nest success rates, and least amount of invertebrate biomass (Duguay et al. 2000). During the post-fledging period, however, regenerating clearcuts received high use by birds that bred in mature forests (Marshall et al. 2003, Vitz and Rodewald 2006, Chandler et al. 2012). In North Carolina, clearcut harvest, roads, and thinning created open spaces used by whip-poor-will's (Caprimulgus vociferous) (Wilson 2003). In an IFM landscape in Maine, recent clearcuts and mature hardwood forests had lowest diversity, but avian species diversity was greatest in forests harvested 6-20 years before (Hagan et al. 1997).

Limited information is available for amphibian response to IFM. However, other studies potentially provide insights. Clearcutting can have greater negative impacts in the near term than partial or selective harvests on amphibians (Petranka et al. 1994, deMaynadier and Hunter 1995, Herbeck and Larsen 1999, Bartman et al. 2001, Knapp et al. 2003, Hocking et al. 2013), likely due to removal of canopy cover that results in a warming and drying of the forest floor (deMaynadier and Hunter 1995, Harpole and Haas 1999, Knapp et al. 2003, Tilghman et al. 2012). Short-term salamander declines of $62 \%(95 \% \mathrm{CI}=29-80 \%)$ were associated with clearcutting in a meta-analysis (Tilghman et al. 2012), although many historical amphibianforestry studies did not account for detection probability, potentially confounding occupancy and 


\section{DRAFT Terrestrial Vertebrate Biodiversity and IFM in the U S}

abundance estimates (Kroll et al. 2008, Kroll 2009). Generally, salamander richness and abundance were positively correlated with stand age (North Carolina, Petranka et al. 1994; Oregon and Washington, Kroll et al. 2008). When mature forest was clearcut, salamander populations were dramatically reduced, or emigrated into the soil profile or out of the harvest area where they were not detectable (Petranka et al. 1994, Semlitsch et al. 2008, Otto et al. 2014). After the effects of the initial disturbance, populations slowly increased over time (Petranka et al. 1994). Buffers around headwater streams and conservation of mature forest were recommended to aid salamander populations (Petranka et al. 1994). In contrast, clearcutting had no discernible negative effects on newly metamorphosed mole salamanders (Ambystoma talpoideum) in pine forests of South Carolina (Chazal and Niewiarowski 1998). Similarly, female size, fecundity, and age classes of plethodontid salamanders did not differ among varying amounts of canopy removal in the Appalachian Mountains of Virginia and West Virgina (Knapp et al. 2003). Although salamander numbers generally decline immediately following timber harvest, extirpations from harvested sites are rare (Tilghman et al. 2012, Harper et al. 2015).

Clearcutting more likely has a positive effect on amphibians during the larval aquatic stage, but negatively affects abundance during terrestrial stages (Hocking and Semlitsch 2007, Semlitsch et al. 2009). In Missouri, gray tree frogs (Hyla versicolor) laid significantly more eggs and a greater number of males were captured within clearcuts compared to a partial harvest and mature forest (Hocking and Semlitsch 2007). Male mole salamanders tended to display greater survival rates than females when originating from clearcut patches, whereas both sexes of salamander showed similar survival rates in unaltered forest (Raymond and Hardy 1991). Survival was greater for individuals that moved to the unaltered forest than for those that moved to patch clearcuts, suggesting that the habitat change may have a negative impact on mole 


\section{DRAFT Terrestrial Vertebrate Biodiversity and IFM in the U S}

salamander populations (Raymond and Hardy 1991). Following a review of the literature,

Russell et al. (2004) concluded that effects of silvicultural practices on herpetofauna often are region- and species-specific, with individual taxa responding positively, negatively, or not at all in the short term. They further noted that response of herpetofauna to forest harvesting is likely related to adaptations of taxa to historical disturbance regimes.

Effects of clearcutting on mammals are highly variable among species (Soutier 1979, Campbell and Clark 1980, Fuller et al. 2004). A meta-analysis of small mammal response to several types of harvest and stand replacing wildfire found a positive or neutral reponse to clearcutting for all but one species (red-backed vole; Myodes gapperi) considered (Zwolak et al. 2009). In the Bridger-Teton National Forest in Wyoming, small mammal captures in clearcuts were skewed toward deer mice ( $80 \%$ of captures) whereas in partially harvested stands, voles (Microtus spp.) represented 76\% captures (Campbell and Clark 1980). Overall abundance of small mammals and microtine rodents increased within clearcut patches in both deciduous and coniferous forests (Kirkland 1990). In a comparison of small mammal populations in a clearcut area and mature forest, small mammal abundance was significantly greater within the clearcut area, although both sides experienced declines (Kirkland et al. 1985). American marten (Martes americana; hereafter marten) abundance was negatively affected in the near term by final harvest (Soutiere 1979, Fuller and Harrison 2005) although patches with trees $>6 \mathrm{~m}$ in height were used by marten (Chapin et al. 1998). Martens avoided clearcuts, although abundance was comparatively greater in partially harvested stands during leaf on (Fuller and Harrison 2005). Consolidation of clearcuts to retain large patches of more mature forest suitable for marten may be a way to offset some of these concerns (Chapin et al. 1998).

\subsection{Managing coarse woody debris during final harvest}




\section{DRAFT Terrestrial Vertebrate Biodiversity and IFM in the U S}

Intensively managed stands often have less CWD than unmanaged stands (e.g., Spies and Cline 1988, Duvall and Grigal 1999), and thus reduced habitat suitability for vertebrate species associated with this habitat element (Duvall and Grigal 1999). Concerns over reduced volumes of CWD in managed forest stands have led to biomass harvesting guidelines in some states (Abbas et al. 2011, Forest Guild 2013). These guidelines can be effective in setting CWD goals as part of biomass harvests (Fritts et al. 2014). Riffell et al. (2011) used 745 effect sizes from 26 studies to examine biodiversity responses on sites where CWD was manipulated. Negative effects on biomass of invertebrates and diversity and abundance of cavity and open-nesting birds were associated with reduction of CWD (Riffell et al. 2011). However, Riffell et al. (2011) found little evidence for large or consistent responses by mammals, reptiles, or amphibians to CWD and snag manipulations. Additionally, research in North Carolina, using recommended biomass harvesting guidelines (Forest Guild 2013), found little response from numerous taxa relative to levels of retained biomass including winter birds (Grodsky et al. 2016), shrews (Fritts et al. 2014), and herpetofauna (Fritts et al. 2016a). In contrast, Lohr et al. (2002) found in South Carolina that breeding bird abundance, abundance of resident bird species, breeding bird diversity, and breeding species richness were reduced by removal of CWD and snags. Weak excavating and secondary cavity nesters had fewer territories on plots with CWD removed (Lohr et al. 2002).

Otto and others (2013) concluded salamander counts were positively correlated with down woody material based on review of peer-refereed literature on amphibian responses to CWD in managed forests throughout North America. Homyack and Kroll (2014) examined relationships between plethodontid salamanders, intensive forest management, and CWD and found the strength of relationships between plethodontid salamanders and CWD was dependent 


\section{DRAFT Terrestrial Vertebrate Biodiversity and IFM in the U S}

on species, region (western vs. eastern forests), and spatial scale. For downed wood and canopy cover, effect sizes of the relationships tended to be imprecise (Otto et al. 2013), suggesting that other factors affect salamanders. Although few studies have evaluated relationships between amphibian vital rates and structural retention, terrestrial salamander survival was positively related to canopy and downed wood retention in Michigan (Otto et al. 2014). Similarly, abundances of ensantina (Ensatina eschscholtzii) and clouded salamanders (Aneides ferreus) were positively correlated with CWD volume in western Oregon. The authors concluded that greater volumes of CWD, exceeding current guidelines, may be necessary for maintaining certain vertebrate species in some locations (Butts and McComb 2000).

Studies on small mammals failed to identify consistent patterns in response to CWD, often highlighting species-specific habitat affinities. In western Oregon, abundance of Trowbridge's shrew (Sorex trowbridgii) was positively correlated with CWD volume (Butts and McComb 2000). In northwestern New Brunswick, there were no meaningful correlations between overall small mammal abundance and individual downed logs or stand level amounts of CWD, but there was a significant relationship between red-backed vole (Myodes gapperi) abundance and CWD (Bowman et al. 2000). In contrast, a study in South Carolina found that certain small mammal species were significantly more abundant in a stand with plentiful CWD (unsalvaged) than in a stand with CWD removed (salvaged; Loeb 1999). Southern short-tailed shrews (Blarina carolinensis), cotton rats and cotton mice (Peromyscus gossypinus) had greater abundances in unsalvaged stands. Cotton mice in particular were in better breeding condition in unsalvaged stands. Fox squirrels (Sciurus niger) were not found within the unsalvaged stand, while they were the second most abundant species in the stand with removed CWD (Loeb 1999). 


\section{DRAFT Terrestrial Vertebrate Biodiversity and IFM in the U S}

In IFM of northern California, small mammal relative abundance was positively correlated with shrub cover and CWD, but shrub cover was more important than CWD (Gray et al. 2016).

In ecosystems with rapid decomposition rates and those historically subjected to frequent fire, large amounts of CWD did not accumulate and recent studies suggest minimal vertebrate response to woody biomass harvests. For example, vegetation characteristics appeared to have a stronger impact on small mammal captures than retained levels of woody biomass in Georgia (Farrell 2013) and California (Gray et al. 2016), and on relative abundance of winter birds (Grodsky et al. 2016) and on captures of three shrew species (Fritts et al. 2015) in regenerating pine in North Carolina. Fritts et al. (2015) found that, although radio-marked southern toads (Anaxyrus terrestis) used CWD, other cover sources also were used as refuge sites and toads did not select CWD cover over other diurnal refuge types. There were no differences in herpetofauanal evenness, diversity, and richness among treatments with different levels of retained CWD, and responses in abundance of two species (Anaxyrus terrestris and Gastrophryne carolinensis) were inconsistent (Fritts et al. 2016b). Even with aggressive woody biomass removal in the absence of biomass harvesting guidelines, large amounts of CWD can remain within forest stands (Forest Guild 2013, Fritts et al. 2014).

\subsection{Set Asides}

\subsubsection{Retained Structures}

Retained structural elements (e.g., green trees, snags, downed wood, retained areas, SMZs) are used to increase structural complexity, provide refugia for forest vertebrates dependent on older forest characteristics (Dellasala et al. 1996, Franklin et al. 1997, Lindenmayer and Franklin 2002, Schieck and Song 2006, Bauhus et al. 2009), and enhance 


\section{DRAFT Terrestrial Vertebrate Biodiversity and IFM in the U S}

landscape connectivity (Rosenvald and Lohmus 2008). Such practices can be non-regulatory (e.g., through state-level, voluntary forestry BMPs) or codified as part of forest practice rules. However, knowledge of quantity and distribution of retained elements needed to meet biodiversity objectives is limited for most forest ecosystems (Bauhus et al. 2009).

Numerous studies have documented relationships among vertebrate species and structural elements (e.g., snags and cavity-nester abundance) in managed forests (summarized in Bull et al. 1997, Johnson and O’Neil 2001:Chapters 4, 24, 27, Rochelle 2008), though few consistent trends or patterns have emerged (Bunnell et al. 1997, Aubry 2000, Rochelle 2008). Additionally, most studies have been of short duration, focusing on structural retention as refugia (Jones et al. 2008, Meggs 2009). The most-studied taxa include birds, amphibians, and small mammals. For all taxa, species-specific responses to structural retention are typical, with responses related to nuances in life history strategies among species and inherent properties of the managed landscapes (Verschuyl et al. 2008; McWethy et al. 2009, 2010). However, some generalizations on effects of structural retention on vertebrate biodiversity are evident from the published literature.

Across IFM landscapes in the U.S., retaining structural elements at time of harvest increased bird species richness (Vanderwel et al. 2007; Hanberry et al. 2012a, 2012b) and increased use of harvested stands by older-forest associated bird species (Meggs 2009, Otto and Roloff 2012), if the surrounding unharvested forests supported those birds. Landscape context strongly influences vertebrate use of retained structures, particularly by mobile organisms such as birds (Kroll et al. 2012a, Linden and Roloff 2015). For example, proportion of older forests adjacent to clearcuts in Oregon was an important predictor of mechanically-created snag use by birds (Kroll et al. 2012a). Conversely, green tree retention had almost no effect on birds in 


\section{DRAFT Terrestrial Vertebrate Biodiversity and IFM in the U S}

relatively small Michigan clearcuts that occurred in a matrix of rotation-aged forests (Otto and Roloff 2012). Rather, stand age (positively correlated with development of vegetation structure in young stands) was a better predictor of bird species richness (Otto and Roloff 2012). Bird species richness was also positively related to proportion of green trees retained (Vanderwel et al. 2007, Meggs 2009) and size of retained patches (minimum of 10-15 trees per patch, Linden et al., 2012). Richness of cavity nesting and tree foraging bird species has been positively related to number of retained snags (Hobson and Schieck 1999; Hanberry et al. 2012a, 2012b), but Linden et al. (2012) failed to detect an effect of snag count and distance to edge on the overall bird community in the Pacific Northwest.

Small mammal species richness and abundance typically respond positively to timber harvest (Constantine et al. 2015), with generalist species showing a wide tolerance to forest disturbance (Raybuck et al. 2012). Structural retention within harvested stands increases small mammal abundance, richness, and diversity (Loeb 1996, Constantine et al. 2004, Gray et al. 2016). Evidence also suggests that rodent assemblages in retention patches can be more similar to adjacent unharvested forests when compared to clearcuts without retention (Constantine et al. 2004), providing some support for retention providing refuge for older forest-dependent small mammals. Although the focus of most retention studies on small mammals has been on green trees and downed wood (Jones et al. 2008, Meggs 2009), Lantschner et al. (2011) and Gray et al. (2016) found that small mammals were positively correlated with understory vegetation diversity and abundance. Similarly, shrew abundance increased as revegetation occurred in harvested pine plantations in North Carolina, and was more closely associated with vegetation recovery than downed wood (Fritts et al. 2015). 


\section{DRAFT Terrestrial Vertebrate Biodiversity and IFM in the U S}

Ecological mechanisms underlying retained structure use by terrestrial vertebrates are complex and encompass multiple temporal and spatial scales and hierarchical levels. Effect of structural retention on biological diversity depends on whether resulting habitat complexity meets habitat requirements of individual species (Tews et al. 2004, Otto et al. 2013, 2014). These effects are mediated by large-scale phenomena such as energy availability, stand productivity, and other inherent components of IFM landscapes (Verschuyl et al. 2008, McWethy et al. 2009, 2010).

\section{Vertebrate Biodiversity and IFM Landscapes}

Landscapes with frequent disturbances, either naturally or due to intensive forest management, have a high degree of habitat heterogeneity, often with interspersion of different ages and sizes of even-aged forests, set-asides and SMZs, roads, edges, and other features. Patch sizes and habitat fragmentation resulting from intensive forest management alter how vertebrate species use landscapes (Jules et al. 1999, Fahrig 2003, Ries and Sisk 2004, Ries et al. 2004), causing changes in species richness, densities, movements and interactions within a system (Wiens et al. 1993).

\subsection{Patch effects}

Effects of patch size and habitat fragmentation in intensively managed landscapes can be difficult to isolate because vertebrate responses are confounded by scale. For example, abundance and distribution of southern red-backed voles (Clethrionomys gapperi) and woodland jumping mice (Napaeozapus insignis) were positively correlated with the diversity of habitat types and level of fragmentation around sampled patches at distances $<275 \mathrm{~m}$ (Bowman et al. 2001). However, no relationships to habitat types or fragmentation were found at the largest distance $(500 \mathrm{~m})$ (Bowman et al. 2001). Density of old field mice (Peromsycus polonotus) did 


\section{DRAFT Terrestrial Vertebrate Biodiversity and IFM in the U S}

not vary among three size classes of clearcut forests $(<6,10-15$, and $>25$ ha; Yates et al. 1997). However, relative density of cotton rats and all other species combined appeared to increase with patch size (Yates et al. 1997), but that relationship is likely not linear. For example, a simulation study suggested that intermediate clearcut sizes were best for conservation of early seral species because wildlife response depended on the ability of a species to perceive and move to neighboring patches with appropriate habitat (Acuna and Estades 2011). Hence, large clearcuts may be incompatible with early seral vertebrate species that have limited dispersal capacity, unless dispersal can be facilitated through corridors or thoughtful planning of clearcut locations (Acuna and Estades 2011). Species diversity had a significant positive correlation with patch size (Yates et al. 1997), but some species (e.g., white-footed mice [Peromyscus leucopus] and shorttailed shrews [Blarina brevicauda]) may decline if clearcuts are too large ( $>4$ ha in southern Indiana; Kellner et al. 2013).

Patch characteristics and scale also affect inferences on bird responses to heterogeneous landscapes. Forest cover was positively correlated with nest success at three spatial scales $(5 \mathrm{~km}$, 10, km, and $25 \mathrm{~km}$ ) evaluated across 13 studies throughout the U.S. (Hartley and Hunter 1998). Almost one-third (29\%) of species were most sensitive to local variables (i.e., vegetation composition), whereas $67 \%$ were most sensitive to landscape variables (i.e., forest cover, core area, edge density and patch size) (Howell et al. 2000). Similarly, presence, abundance, and diversity of early seral bird species was best explained by microhabitat variables (as opposed to stand-level variables) in even-aged stands in West Virginia (McDermott et al. 2011). Stand-level variables had greater utility in predicting occurrence and abundance of late-successional bird species (McDermott et al. 2011). Distance from roads and heterogeneity of patch ages in managed forest landscapes positively influenced richness of most bird guilds (Loehle et al. 


\section{DRAFT Terrestrial Vertebrate Biodiversity and IFM in the U S}

2005a, Mitchell et al. 2006), but in Maine most bird species preferred homogenous over heterogeneous landscapes (Hagan et al. 1997).

\subsection{Edge effects}

Edge characteristics can be transitional or abrupt, of different widths, and can be formed by any number of cover type combinations (Yahner 1988). Edges are common in IFM landscapes. They are created via adjacent harvest units of differing ages and where managed forests adjoin other cover types — including unmanaged forest, agricultural areas, and roads (deMaynadier and Hunter 1998). Edges frequently support greater biodiversity, likely related to the complex ecotone created by multiple, adjacent habitat types (Strelke and Dickson 1980). As generalist species effectively take advantage of edges, there is concern that specialists may be adversely affected (Strelke and Dickson 1980).

Distribution of small mammals was more closely tied to vegetation type than edge in managed loblolly pine in South Carolina (Constantine et al. 2015) with rodents more abundant in harvested stands (Constantine et al. 2015). White-footed mice and eastern chipmunks (Tamius striatus) traveled across a clearcut and mature forest boundary, suggesting that clearcut edges were permeable for some small mammal species (Kirkland et al. 1985). In contrast, California red-backed voles (Clethrionomys californicus) appeared to avoid clearcuts in southwest Oregon, effectively isolating themselves in unharvested forest patches (Mills 1995). Abundance of northern red-backed voles (Myodes rutilus) increased dramatically along forest edges, displaying a positive edge effect (Mills 1995). Similarly, several species of bats consistently used edges in IFM of the southeastern U.S. (Morris et al. 2010, Law et al. 2016). Bats appear to use edges as travel conduits and foraging locations (Morris et al. 2010, Kalcouins-Rueppell et al. 2013), with 


\section{DRAFT Terrestrial Vertebrate Biodiversity and IFM in the U S}

occupancy positively associated with overstory height and negatively with adjacent stand age (Hein et al. 2009).

Edge effects on birds have been widely examined, mostly in the context of nesting success. Generally, birds experience increased nest predation along edges, but these effects vary by broad forest type with marshes and deciduous forests experiencing significant nest predation (Batáry and Báldi 2004). In coniferous forests, tropical forests, and fields, edge effects were not detected (Batáry and Báldi 2004). Edge characteristic can also be an important determinant of nest success. For example, indigo buntings (Passerina cyanea) experienced higher nest depredation along permanent, abrupt edges compared to edges with gradual transitions (Suarez et al. 1997). Landscape context is an important determinant of edge effects. For example, in mostly forested landscapes of northern Minnesota, distance to forest edge had no effect on nesting success in stands of varying ages (i.e., recent clearcuts to forests >8 m tall; Hanksi et al. 1996). In contrast, nest predation rates were higher when forest patches and resulting edges were embedded in a landscape of residential development (Keyser 2002).

\subsubsection{Streamside management zones}

Streamside management zones are strips of forest vegetation along waterways managed in a way to meet water quality goals (Helms 1998). A large body of research has documented that SMZs are effective in trapping sediment and reducing total suspended sediment concentrations in streams (Cristan et al. 2016). Although SMZs are established for water quality protection, they provide value for terrestrial vertebrates, whose species richness generally increases with SMZ width, but most benefits can occur in relatively narrower SMZs (Wigley and Melchiors 1994). 


\section{DRAFT Terrestrial Vertebrate Biodiversity and IFM in the U S}

Use of SMZs by vertebrates depends on vegetation structure within the SMZ and adjacent forest. Some evidence exists that SMZs provide travel conduits for songbirds and bats in IFM that prefer mature forest (Johnson and Brown 1990 [Maine], Triquet et al. 1990 [Virginia], Law et al. 2016). Width of the SMZ may be less important than adjacent forest type (Miller et al. 2004, Pearson et al. 2015), except for eastern wild turkey (Meleagris gallopavo silvestris; Burk et al. 1990) and amphibians (Powell and Babbitt 2015). In southern IFM landscapes, narrow SMZs had greater small mammal abundance and richness than wider SMZs (Dickson and Williamson 1988, Miller et al. 2004). Further, SMZs adjacent to plantations with open canopies tended to have even greater levels of small mammal richness and abundance than those adjacent to plantations with mature, closed canopies (Miller et al. 2004; also see Tassone 1981 for a similar result in Virginia). Although Tassone (1981) found that populations of interior forest birds were positively correlated to SMZ width in Virginia, they did not account for adjacent forest characteristics. Landscape context influences how SMZs will affect vertebrates (e.g., Pearson et al. 2015). For example, to protect stream ecosystems in the Pacific Northwest, SMZs incorporated complex waterways with access to CWD and floodplain connections, which allowed for a greater diversity of vegetation associations (Bisson et al. 1992).

\subsubsection{Forest road ditch systems}

Intensively managed forest landscapes also often contain man-made ditches, especially in low-lying areas that were formerly agricultural lands, that are associated with the forest road network and provide habitat for reptiles and amphibians. In eastern North Carolina, 15 species of frogs and toads were detected in ditches imbedded within an IFM landscape (Homyack et al. 2014b). In a companion study, Homyack et al. (2016), detected 25 species of amphibians and reptiles in roadside ditches, including 5 species of statewide conservation concern. The authors 


\section{DRAFT Terrestrial Vertebrate Biodiversity and IFM in the U S}

concluded that ditch maintenance activities had little effect on occupancy or richness. Similarly, O'Bryan et al. (2016) documented persistence of a species of concern, the spotted turtle, in roadside ditches in an intensively managed pine landscape in eastern North Carolina.

\section{Landscape context and biophysical factors}

Intensive forest management is most common in highly productive forested locations (e.g, Pacific Northwest, southeastern Coastal Plain) due to favorable growing conditions for crop trees. In these high productivity locations, IFM may result in compression of successional stages and rapid competitive dominance of planted trees (Verschuyl et al. 2008, see Miller et al. 2009 for a southern example). In high productivity stands with rapidly growing planted trees, understory shrub development may be limited to open-canopy settings, persisting for only a few years before being replaced by tree seedlings (McWethy et al. 2010). However, non-coniferous understory vegetation in young stands offers more productive food resources for some birds than regenerating conifers (Hagar 2007). In such cases, timber harvest can break competitive dominance of overstory species and free resources, increasing diversity of plant and vertebrate species (Huston 1999, Loehle et al. 2002, Verschuyl et al. 2008, McWethy et al. 2010). Because energy-rich forested environments often contain greater numbers of species specialized in forest interior, edge, or early-seral conditions (McWethy et al. 2009, 2010), the shifting mosaic of different seral stages that results from intensified forest management may increase diversity at landscape scales in productive locations (Loehle 2002, Tappe et al. 2004, Verschuyl et al. 2008, Kroll et al. 2014).

In lower energy landscapes, biodiversity may be concentrated in 'hotspot' locations (Verschuyl et al. 2008), where overstory species dominance and competitive exclusion of other species was often limited by site conditions, and increased within-stand heterogeneity reduced 


\section{DRAFT Terrestrial Vertebrate Biodiversity and IFM in the U S}

effects of stand edge, or other stand adjacency measures on vertebrates and biodiversity

(McWethy et al. 2009). Further, these naturally heterogeneous forest landscapes often have fewer species that specialize in a particular seral stage (McWethy et al. 2010).

Landscape measures of vertebrate biodiversity may be maximized in locations where IFM stands are in close proximity to less intensively managed lands, as is often the case with adjacent public and private ownerships in the Pacific Northwest (McWethy et al. 2010). Finally, landscape context may affect biodiversity or individual species' responses to certain stand or local scale habitat features (Tscharntke et al. 2012). However, in the Southeast, landscape context (percentage of mature hardwood forest) did not alter the relationship between stand scale habitat measures and bird species richness or occupancy (Kroll et al. 2014).

\section{Discussion}

As the human population grows, application of IFM practices will likely become an increasingly important component of meeting societal demands for wood products. Thus, understanding relationships among aspects of biodiversity and IFM is vital to ensuring health and productivity of forest ecosystems and, subsequently, human health. Our review of the current literature revealed some general trends about vertebrate biodiversity and IFM. However we caution that such generalizations vary considerably depending on location, species, and study methodologies and systems. Lack of data on terrestrial vertebrate responses to IFM for a variety of taxa in diverse geographic and physiographic settings where IFM occurs also limits generalizations. It is also often not possible to examine biodiversity responses before and after implementation of IFM thus further limiting inferential space (see research needs section). 


\section{DRAFT Terrestrial Vertebrate Biodiversity and IFM in the U S}

Finally, although we compartmentalized our review sequentially with practices often associated with establishing and developing IFM, we acknowledge that these practices are not applied in isolation and likely have cumulative and interactive effects on terrestrial vertebrate diversity (Swift and Bell 2011).

Predominantly, terrestrial vertebrate responses to IFM are indirect, related to changes in vegetation associations, coupled with successional changes. We found both positive and negative indirect effects of intensive forest management on terrestrial vertebrates. The positive contributions of IFM to vertebrate diversity are not negligible and should be considered in local and regional conservation-planning efforts (see below). Managed forest stands and landscapes in all regions we evaluated tended to support diverse and abundant terrestrial vertebrate communities, particularly early seral species and generalists. Although some negative effects of IFM at the stand level appeared to be short-term (e.g., chemical effects on plant communities), others may be longer lasting with potentially significant negative long-term consequences to terrestrial vertebrate populations (e.g., recruitment of mature forest structures like CWD and snags, shortening the forest successional trajectory). Most institutional forest landowners have implemented practices to ameliorate these potential negative long-term effects (e.g., providing structural retention and SMZs in harvest units, managing for a mosaic of different forest age classes), but effectiveness of these practices remains a research need. We can also generalize that intensity of stand-level management practices correlated negatively with vertebrate diversity, which emphasizes importance of managers considering using the least intensive and most costeffective silvicultural practices available to accomplish productivity objectives. Managers also need to understand consequences of management practices, including those that directly benefit terrestrial vertebrate communities (e.g., prescribed fire), when planning forest activities. 


\section{DRAFT Terrestrial Vertebrate Biodiversity and IFM in the U S}

An important complicating factor in understanding effects of IFM on terrestrial vertebrates is the confounding influence of forest succession. Our review found that forest successional stages were important in determining terrestrial vertebrate occupancy and abundance in IFM and that long-term successional changes were often more important than short-term effects from some silvicultural practices (e.g. herbicide use, site preparation technique). However, because forest management practices can influence successional trajectories, interaction of these practices with forest succession cannot be ignored. Long-term (rotational length if possible), replicated field experiments with true controls (no forest management activities following harvest) are needed to more fully understand these complex relationships.

\subsection{Contributions of IFM to conservation planning}

Although there are potentially negative indirect effects of IFM practices on biodiversity, IFM stands and landscapes provide appropriate habitat conditions, often at multiple scales, for many vertebrate species, including species of high conservation priority. At the stand scale, intensive management can yield forest structural conditions that emulate historical conditions in regions such as the southeastern U.S. (e.g., Hedman et al. 2000, Iglay 2010, Jeffries et al. 2010, Lane et al. 2011, Singleton et al. 2013), with benefits to native terrestrial vertebrate species and regional conservation of biodiversity (Miller et al. 2009). In landscapes that lack early successional forests, intensive management can provide a forest successional stage important for disturbance-associated terrestrial vertebrates. Given that early successional species are among those experiencing the most dramatic long-term declines (e.g., King and Schlossberg 2013), providing early seral conditions is of critical importance. Providing a forest stands of different ages and types across landscapes may provide dispersal opportunities for terrestrial vertebrate 


\section{DRAFT Terrestrial Vertebrate Biodiversity and IFM in the U S}

species across a landscape, especially when IFM are imbedded in a landscape of unmanaged or less intensively managed areas (Loehle et al. 2005, Miller et al. 2009, Posner 2012, Tappe et al. 2004). In some instances (e.g., Pacific Northwest) large areas of IFM that restrict public access provide refugia for vertebrates like elk (Cervus elaphus) and deer; these landscapes can also help control access and reduce poaching opportunities for game species..

In addition to these conservation contributions, intensive management facilitates efficient production of forest products from smaller areas, allowing other management objectives, such as maintenance of biodiversity, to take precedence elsewhere (Sedjo and Botkin 1997, Fox 2000, Allen et al. 2005, Payn et al. 2015, Tittler et al. 2015). Additionally, societal demand for forest products provides economic incentives for maintaining forest cover (Lubowski et al. 2008). These incentives maintain forested area and encourage improved productivity, supporting investments in sustainable forest management (Wear 2013, Miner et al. 2014), thereby providing habitat for forest-dependent vertebrates (e.g., Bender et al. 2015). Expanded investment in IFM due to strong markets for wood varies regionally, but is especially evident in the southeastern U.S. (Miner et al. 2014).

\subsection{Challenges of intensively managed forest and conservation strategies}

Despite biodiversity contributions, challenges exist for accommodating vertebrate communities in IFM stands and landscapes. Intensive forest management can suppress certain plant species, alter and truncate forest succession, and alter availability of habitat features for certain species (Guynn et al. 2004, Jones et al. 2010, Jones et al. 2012). Intensive forest management results in frequent, consistent forest disturbances that create shifting landscape mosaics of even-aged stands in various stages of succession, interspersed with mature forest stands, roads, forest openings, and other features. While contributing to habitat needs of many 


\section{DRAFT Terrestrial Vertebrate Biodiversity and IFM in the U S}

terrestrial vertebrate species, frequent disturbances and rapid succession can negatively affect other species, particularly specialists associated with mature forest structural components (e.g., Homyack and Kroll 2014). Other negative consequences include compression of seral stages, lack of mature forest components within intensively managed stands (e.g., snags, large debris, canopy heterogeneity), and creation of edges (Miller et al. 2009).

Some of these limitations can be ameliorated through active management practices at the stand scale. Site preparation buffers around retention areas and SMZs, intermediate thinning, prescribed burning, and retention of some structural features during the forest management cycle can help diversify vegetation conditions and minimize duration of closed canopy conditions, which are generally the less-diverse stand development stage (although there are exceptions for some species). In some regions, these activities allow intensively managed stands to better emulate historic forest conditions (Greene et al. 2016, Iglay et al 2014b). Although individual stands may have temporally compressed seral stages, periodic forest disturbance across the landscape provides a moving mosaic of forest conditions through time. Mobile organisms such as birds and larger mammals move through these landscapes, using different locations as appropriate habitat becomes available (Acuna and Estades 2011). Spatially explicit harvest scheduling software, such as Habplan (http://www.ncasi2.org/; Van Deusen 1999, 2001), allows managers to consider implications of alternative management regimes to create or maintain forest conditions of interest over time. For example, a study recently used such software to determine that almost half of an IFM landscape could be maintained in open-canopy conditions appropriate for gopher tortoises (Gopherus polyphemus) over a 90-year period through application of typical forest management regimes that included clearcutting and thinning (R. A. Greene, unpublished data, Mississippi State University). 


\section{DRAFT Terrestrial Vertebrate Biodiversity and IFM in the U S}

Unique areas, set asides or retained areas, and retained structures (e.g., snags, CWD) provide value for vertebrates in IFM landscapes. Within IFM landscapes, retained patches and buffers, inoperable areas, small habitat features such as isolated wetlands, downed wood, and other edaphic features, can strongly influence presence and abundance of reptiles, amphibians, and other species irrespective of stand-level characteristics (Russell et al. 2002, Shipman et al. 2004, Iglay et al. 2014a, O'Bryan 2014, Johnson et al. 2016, Homyack et al. 2016). Forest certification programs require participants to retain these habitat elements. Additionally, forest certification requires consideration of rare species and communities. Rare ecological communities should be managed to retain their unique values, and research should be conducted to further elucidate the value they bring to biological diversity within the broader forest landscape and to understand potential management options to maintain their integrity (e.g., Posner 2012).

Finally, managers should consider the influence of context (e.g., proximity of agriculture, residential or urban development, private or public ownership) of silvicultural operations on the terrestrial vertebrate species pool available for colonization (Lindenmayer et al. 2009, Le Roux et al. 2016), presence of pests or predators that might negatively affect desirable vertebrate species (Homyack et al. 2014, Howell et al. 2007, Cox et al. 2012, Etterson et al. 2014), and management decisions on vertebrate conservation that potentially transcend ownership boundaries (e.g., northern spotted owl conservation in the Pacific Northwest; Loehle et al. 2015). Additionally, land management legacy (e,g., agricultural vs. always being forested) affects plant communities and thus vegetation conditions (Hedman et al. 2000, Burke et al. 2016). In these situations, the same silvicultural treatments may result in different vegetation community responses, even in areas geographically close (e.g., Miller and Miller 2004). Overall, when 


\section{DRAFT Terrestrial Vertebrate Biodiversity and IFM in the U S}

making management decisions, landscape context, historical land use, and inherent biodiversity potential are important to terrestrial vertebrate diversity on IFM landscapes.

\subsection{Research needs}

Although much research has documented terrestrial vertebrate responses to IFM, we acknowledge that more work is needed to understand larger scale processes over longer time frames. For example, IFM landscapes provide a shifting mosaic of habitat conditions (Miller et al. 2009), but it is not clear how many species are, or can, adapt to these rapidly shifting conditions. This is particularly relevant for specialists with low vagility. Forest roads are an important component of IFM landscapes and recent studies have investigated reptile and amphibian communities in ditch systems associated with forest roads (Homyack et al. 2014, 2016; O’Bryan et al. 2016). However, additional study of biodiversity relationships with forest road systems is warranted. We also suggest more research on effects of intensive forest management practices on vertebrate vital rates, as abundance can provide misleading inference on population performance (e,g., Abele et al. 2013, Otto et al. 2014). More research is needed on effects of IFM within a landscape context (Tscharntke et al. 2012), especially if it is (1) the predominate forest system in a given landscape; (2) is imbedded or interspersed with other forest management systems (e.g. interspersed with public land); or (3) isolated in other landscape types, such as large areas of predominantly agricultural landscapes.

Most research has historically been of relatively short ( $<5$ years) duration thereby documenting short-term effects of biodiversity response to silvicultural treatments (e.g., herbicide use, site preparation). Jeffries et al. (2010) found strong similarities in the herbaceous layer of loblolly pine stands across multiple rotations, but some key differences in species composition including persistence of disturbance-responsive species in third rotation plots where 


\section{DRAFT Terrestrial Vertebrate Biodiversity and IFM in the U S}

vegetation control treatments were applied. However, we failed to find any long-term studies that documented vertebrate biodiversity response throughout an entire timber rotation or across multiple rotations on IFM (but see Jokela et al. 2010 for a study on a rotation-length experiment on long term productivity of southern pine). Depending on the region, this may require a 30-70 year commitment to monitoring, though sampling intervals (corresponding to different forest development stages) would most likely be adequate. Long-term, longitudinal information would greatly increase our ability to understand values of managed forests for biodiversity while providing data for larger scale modeling efforts (Kroll 2009). It is also important to realize that current patterns of terrestrial vertebrate response to IFM are at least partially resultant from practices employed $30+$ years ago. Therefore, it is critical to continue to examine terrestrial vertebrate communities to build knowledge of current technologies.

We need a better understanding of how varying amounts and spatial distributions of retained structures, mature or natural forest stands, and areas of ecological significance contribute to biodiversity (Kroll et al. 2012b). There are significant research gaps in understanding effects of thinning on reptile and amphibian communities (Verschuyl et al. 2011) and long-term implications of multiple rotations for biodiversity (e.g., Jeffries et al. 2010). The long-term, landscape-level effects of shortened early successional stages of forest development affects multiple vertebrate species, but these effects also have been poorly documented. Demand for increased efficiency of forestry operations may cause increases in IFM land use on both currently forested and non-forested lands, heightening the need for study of IFM impact on biodiversity. Concomitant with this is a need to examine biodiversity patterns and process relative to the absence of IFM and relative to alternative land uses. Most studies have documented biodiversity value using application of various treatments in an experimental 


\section{DRAFT Terrestrial Vertebrate Biodiversity and IFM in the U S}

framework, but without a control representing these two alternative landscape conditions. This limits our understanding of how IFM are able to emulate processes in non-IFM systems. Of particular relevance is a better understanding of age distribution of forest stands on intensively managed landscapes and how this affects biodiversity potential compared to historical forest conditions and other land uses.

Forestry practices are constantly changing as new technologies, methods, and markets arise. Some standard practices employed even 20 years ago are not relevant today. For example, in the southeastern U.S., many institutional forest owners now emphasize management to favor higher value products (e.g., sawtimber) and, due to advances in forest inventory and remote sensing technologies, are able to better match management practices to site-specific conditions. However, the future of intensive forest management likely entails continued use of genetically improved tree seedlings, planting at lower stocking densities to meet conservation objectives (Leblond et al. 2015), herbicides and fertilizers to enhance tree growth, and pesticides to help control insects and diseases (e.g., Hanselmann and Jolles 2012). Therefore, it is imperative to develop research hypotheses, based on ecological knowledge and past research, to examine changing and emerging forest practices relative to biodiversity. This certainly includes changing strategies to meet new markets (e.g., biomass markets). Strategic thinking is required to ensure that a long-term investment on research produces results that are relevant over the long-term and can be used to help guide conservation decisions.

As noted in the introduction, our review concentrated on terrestrial vertebrates. However, it is clear that invertebrate communities are critical to sustainability of forest conditions (e.g., Rosenberg et al. 1986, Hammond and Miller 1998, Werner and Raffa 2000, Iglay et al. 2012c). Invertebrate communities provide unique challenges to achieving adequate 


\section{DRAFT Terrestrial Vertebrate Biodiversity and IFM in the U S}

sampling for reliable results due to community complexity and their diversity of life history strategies. However, a full understanding of IFM effects on biodiversity requires consideration of invertebrate communities (Iglay et al. 2012c). This appears to be particularly relevant as concerns about pollinator communities continue to escalate (Chagnon 2008).

\subsection{Conclusion}

In a rapidly developing world, IFM will continue to be an important component of the North American landscape and resource for conservation of terrestrial vertebrate diversity. Over time, IFM has advanced and forest managers now tend to tailor management to site-specific conditions and apply only those practices required to meet silvicultural and other objectives. Increased production of industrial wood from IFM allows harvest to be concentrated on a smaller area, provides landowners with a financial incentive to maintain forest cover, and allows other objectives in other portions of the landscape. Management of IFM in the U.S. also occurs within the context of a rigorous network of laws, regulations, and guidelines designed to protect environmental quality. Furthermore, intensive forest management is often under auspices of forest certification programs or wood is sourced from IFM through a fiber sourcing standard providing further assurance that managers consider biodiversity implications including conservation of at-risk species. We encourage consideration for these contributions in regional conservation plans.

The nature of IFM means that terrestrial vertebrates must contend with frequent disturbance, altered successional stages, changing resources, introduction of edges, and fragmentation at the forest stand scale. While managers must overcome these challenges to ensure that species of concern (as well as overall diversity) are conserved, techniques such as thinning, mid-rotation management, and wide spacing of trees contribute to suitable habitat conditions for a variety of 


\section{DRAFT Terrestrial Vertebrate Biodiversity and IFM in the U S}

species. Due to active management practices such as these, conservation contributions of IFM often complement contributions of less intensively managed forests and alternate land uses in corresponding landscapes and regions.

\section{ACKNOWLEDMENTS}

We appreciate National Council for Air and Stream Improvement, Mississippi State University, Michigan State University, and Weyerhaeuser for support of the authors. Some effort was supported by the National Institute of Food and Agriculture, U.S. Department of Agriculture, McIntire-Stennis project under accession number MISZ 082090. This is Mississippi State University Forest and Wildlife Research Center publication number WFA-XXX. We thank A. J. Kroll and J. A. Homyack for insightful comments and S. Youngbuck for significant editorial support.

\section{References}

Abbas, D., D. Current, M. Phillips, R. Rossman, H. Hoganson, and K. N. Brooks. 2011. Guidelines for harvesting forest biomass for energy: a synthesis of environmental considerations. Biomass and Bioenergy 35:4538-4546.

Abele, S.L., A.J. Wirsing, and D.L. Murray. 2013. Precommercial forest thinning alters abundance but not survival of snowshoe hares. Journal of Wildlife Management 77(1):84-92.

Acuna, M.P., and C.F. Estades. 2011. Plantation clearcut size and the persistence of earlysuccessional wildlife populations. Biological Conservation 144(5):1577-1584.

Agee, J., and C Skinner. 2005. Basic principles of forest fuel reduction treatments. Forest Ecology and Management 211(1-2):83-96.

Allen, H.L., T.R. Fox, and R.G. Campbell. 2005. What is ahead for intensive intensively managed forest silviculture in the South? Southern Journal of Applied Forestry 29(2):6269.

Amacher, A. J., R.H. Barrett, J.J. Moghaddas, and S.L. Stephens. 2008. Preliminary effects of fire and mechanical fuel treatments on the abundance of small mammals in the mixedconifer forest of the Sierra Nevada. Forest Ecology and Management 255(8-9):31933202.

Anthony, R.G., and M.L. Morrison. 1985. Influence of glyphosate herbicide on small-mammal populations in western Oregon. Northwest Science 59: 159168. 
Arano, K.G., and I.A. Munn. 2006. Evaluating forest management intensity: A comparison among major forest landowner types. Forest Policy and Economics 9(3):237-248.

Aubry, K.B. 2000. Amphibian in managed, second-growth Douglas-fir forests. Journal of Wildlife Management 64:1041-1052.

Baker, J.C., and W.C. Hunter. 2002. Chapter 4: Effects of forest management on terrestrial ecosystems. Pages 91-112 in D.N. Wear and J.G. Greis, eds. Southern Forest Resource Assessment - Technical Report. USDA Forest Service General Technical Report SRS-53. 653pp.

Baker, M. D., and M.J. Lacki. 1997. Short-term changes in bird communities in response to silvicultural prescriptions. Forest Ecology and Management 96(1-2):27-36.

Balvanera, P., A. B. Pfisterer, N. Buchmann, J-S He, T. Nakashizuka, D. Raffaelli, and B. Schmid 2006. Quantifying the evidence for biodiversity effects on ecosystem functioning and services. Ecology Letters 9: 1146-1156.

Barber, D. R., T. E. Martin, M. A. Melchiors, R. E. Thill, and T. B. Wigley. 2001. Nesting success of birds in different silvicultural treatments in southeastern U.S. pine forests. Conserv. Biol. 15, no. 1:196-207.

Bartman, C. E., K.C. Parker, J. Laerm, and T.S. Mccay. 2001. Short-term response of Jordan's Salamander to a shelterwood timber harvest in western North Carolina. Physical Geography 22(2):154-166.

Bassett-Touchell, C. A., and P. C. Stouffer. 2006. Habitat selection by Swainson's warblers breeding in loblolly intensively managed forests in southeastern Louisiana. Journal of Wildlife Management 70:1013-1019.

Batáry, P., and A. Báldi. 2004. Evidence of an edge effect on avian nest success. Conservation Biology 18(2):389-400.

Bauhus, J., K. Puettmann, and C. Messier. 2009. Silviculture for old-growth attributes. Forest Ecology and Management 258:525-537.

Bayne, E., and B. Nielsen. 2011. Temporal trends in bird abundance in response to thinning of lodgepole pine. Canadian Journal of Forest Research 41(10):1917-1927.

Beaver, D.L. 1976. Avian populations in herbicide treated brush fields. Auk 93:543553.

Bender, M. J., S. B. Castleberry, D. A. Miller, and T. B. Wigley, Jr. 2015. Site occupancy of foraging bats on landscapes of managed pine forest. Forest Ecology and Management 336:1-10. 
Betts, M. G., J. C. Hagar, J. W. Rivers, J. D. Alexander, K. McGarigal, and B. C. McComb, 2010. Thresholds in forest bird occurrence as a function of the amount of early-seral broadleaf forest at landscape scales. Ecological Applications 20(8): 2116-2130.

Betts, M. G., J. Verschuyl, J. Giovanini, T. Stokely, and A. J. Kroll. 2013. Initial experimental effects of intensive forest management on avian abundance. Forest Ecology and Management 310: 1036-1044.

Bisson, P.A., T.P. Quinn, G.H. Reeves, S.V. Gregory. 1992. Best mangement practices, cumulative effects, and long-term trends in fish abundance in Pacific Northwest river systems. Watershed Management pages 189-232.

Blair, R. M. 1960. Deer forage increased by thinnings in a Louisiana loblolly intensively managed forest. Journal of Wildlife Management 24:401-405.

Blake, P.M., G.A. Hurst, and T.A. Terry. 1987. Responses of vegetation and deer forage following application of hexazinone. Southern Journal of Applied Forestry 11:176-186.

Blinn, C. R. and M. A. Kilgore. 2001. Riparian management practices, a summary of state guidelines. Journal of Forestry 99:11-17.

Bois, G., L. Imbeau, and M.J. Mazerolle, 2012. Recovery time of snowshoe hare habitat after commercial thinning in boreal Quebec. Canadian Journal of Forest Research 42(1):123133.

Borrecco, J.E., H.C. Black, and E.F. Hooven. 1972. Response of black-tailed deer to herbicideinduced habitat change. In Proceedings of the $52^{\text {nd }}$ annual conference of the Western Association of State Game and Fish Commissioners, Portland, Oregon pages 437451.

Borrecco, J.E., H.C. Black, and E.F. Hooven. 1979. Response of small mammals to herbicideinduced habitat changes. Northwest Science 53: 97106.

Bowman, J., G. Forbes, and T. Dilworth. 2001. Landscape context and small-mammal abundance in a managed forest. Forest Ecology and Management, 140:249-255.

Bowman, J.C., D. Sleep, G.J. Forbes and M. Edwards. 2000. The association of small mammals with coarse woody debris at log and stand scales. Forest and Ecology Management 129: 119-124.

Boyd, R. S., J.D. Freeman, B. Edwards, and J.H. Miller 1995. Forest herbicide influences on floristic diversity seven years after broadcast pine release treatments in central Georgia, USA. New Forests:17-37.

Brender, E., and R. Cooper. 1968. Prescribed burning in Georgia's Piedmont loblolly pine stands. Journal of Forestry, 66(1), 31-36. 
Brennan, L. A., R. T. Engstrom, W. E. Palmer, S. M. Hermann, G. A. Hurst, L. W. Burger, Jr., and C. L. Hardy. 1998. Whither wildlife without fire? Transactions of the North American Wildlife and Natural Resources Conferences 63:402-414.

Briones, K. M., J. A. Homyack, D. A. Miller, and M. Kalcounis-Rueppell. 2013. Intercropping switchgrass with loblolly pine does not influence the functional role of white-footed mouse (Peromyscus leucopus). Biomass and Bioenergy 54:191-200.

Brito-Aguilar, R. 2005. Effects of even-aged forest management on early successional bird species in Missouri Ozark forest. Thesis, University of Missouri-Columbia.

Brockerhoff, E., H. Jactel, J. Parrotta, C. Quine, and J. Sayer. 2008. Intensively managed forest and biodiversity: oxymoron or opportunity? Biodiversity and Conservation 17(5):925951.

Brooks, J., M.A.C. Rodrigue, K.V. Miller, B.R. Chapman, and A.S. Johnson. 2001. Small mammal and avian communities on chemically prepared sites in the Georgia sandhills. Proceedings for the Eight Biennial Southern Silvicultural Research Conference. 21.

Brunjes, K.J., K.V. Miller, W.M. Ford, T.B. Harrington, and M.B. Edwards, M.B. 2003. Effects of thinning and herbicide application on vertebrate communities in longleaf pine plantations. Proceedings of the Annual Conference of Southeastern Association Fish Wildlife Agencies 57: 252-267.

Buckner, J., and J.L. Landers. 1979. Fire and disking effects on herbaceous food plants and seed supplies. The Wildlife Society. 43(3):807-811.

Bull, E.L. C.G. Parks, and T.R. Torgersen. 1997. Trees and logs important to wildlife in the interior Columbia River basin. USDA Forest Service General Technical Report PNWGTR-391.

Bunnell, F.L., L.L. Kremaster, and R.W. Wells. 1997. Likely consequences of forest management on terrestrial, forest-dwelling vertebrates in Oregon. Oregon Forest Resources Institute, Portland, Oregon, USA.

Burger, L. W. 2001. Northern bobwhite. Wildlife of southern forests, habitat and management. Hancock House Publishers, Blaine, Washington, USA. 112-146.

Burk, J. D., G. A. Hurst, D. R. Smith, B. D. Leopold, and J. G. Dickson. 1990. Wild turkey use of streamside management zones in loblolly pine plantations. National Wild Turkey Symposium 6:84-89.

Burke, D.J., C. Knisely, M.L. Watson, S.R. Carrino-Kyker, and R.L. Mauk. 2016. The effects of agricultural history on forest ecological integrity as determined by a rapid forest assessment method. Forest Ecology and Management 378:1-13. 
Butler, B.J. 2008. Family forest owners of the United States, 2006: A technical document supporting the Forest Service 2010 RPA Assessment. USDA Forest Service General Technical Report NRS-27.

Butts, S.R. and W.C. McComb. 2000. Associations of forest-floor vertebrates with coarse woody debris in managed forests of western Oregon. The Journal of Wildlife Management 64(1): 95-104.

Campbell, D.L., J. Evans, G.D. Lindsey, and W.E. Dusenberry. 1981. Acceptance by blacktailed deer of foliage treated with herbicides. USDA Forest Service Research Paper PNW-290.

Campbell III, T. M., and T.W. Clark. 1980. Short-term effects of logging on red-backed voles and deer mice. Great Basin Naturalist, 40(2):183-189.

Cardinale, B. J., J. E. Duffy, A. Gonzalez, D. U. Hooper, C. Perrings, P. Venail, A. Narwani, G. M. Mace, D. Tilman, D. A. Wardle, A. P. Kinzig, G. C. Daily, M. Loreau, J. B. Grace, A. Larigauderie, D. S. Srivastava and S. Naeem. 2012. Biodiversity loss and its impact on humanity. Nature 486:59-67

Campbell, T.N., P.D. Jones, S. Demarais, and A.W. Azell. 2015. Vegetation communities in intensively established loblolly pine plantations at crown closure. Journal of Forestry 113(3):298-307.

Carnus, J. M., J. Parrotta, E. Brockerhoff, M. Arbez, H. Jactel, A. Kremer, D. Lamb, K. O'Hara, and B. Walters. 2006. Planted forests and biodiversity. Journal of Forestry 104(2):65-77.

Carter, M. C., and C.D. Foster. 2004. Prescribed burning and productivity in southern pine forests: A review. Forest Ecology and Management 191(1-3):93-109.

Chagnon, M. 2008. Causes and effects of worldwide decline in pollinators and corrective measures. Canadian Wildlife Federation. Quebec Regional Office, Canada.

Chamberlain, M. J., and D.A. Miller. 2006. Effects of two site preparation techniques on biomass of forage plants for white-tailed deer in eastern Louisiana. Proceedings of the Annual Conference South East Association Fish and Wildlife Agencies 64-69.

Chandler, C.C., D.I. King, and R.B. Chandler. 2012. Do mature forest birds prefer earlysuccessional habitat during the post-fledging period? Forest Ecology and Management 264:1-9.

Chapin, T., D. Harrison, and D. Katnik. 1998. Influence of landscape pattern on habitat use by American marten in an industrial forest. Conservation Biology 12(6):1327-1337.

Chazal, A.C., and P.H. Niewiarowski. 1998. Responses of mole salamanders to clearcutting: Using field experiments in forest management. Ecological Applications 8(4): 1133-1143. 
Cole, E.C., W.C. McComb, M. Newton, J.P. Leeming, and C.L. Chambers. 1998. Response of small mammals to clearcutting, burning, and glyphosate application in the Oregon Coast Range. Journal of Wildlife Management 62: 12071216.

Conde, L. F., B.F. Swindel and J.E. Smith. 1983. Plant species cover, frequency, and biomass: early responses to clearcutting, chopping and bedding in Pinus elliottii flatwoods. Forest Ecology and Management 6:307-317.

Conroy, M. J., R. G. Oderwald, and T. L. Sharik. 1982. Forage production and nutrient concentrations in thinned loblolly intensively managed forests. Journal of Wildlife Management 46:719-727.

Constantine, N., T.A. Campbell, W.M. Baughman, T.B. Harrington, B.R. Chapman, and K.V. Miller. 2004. Effects of clearcutting with corridor retention on abundance, richness, and diversity of small mammals in the Coastal Plain of South Carolina, USA. Forest Ecology and Management 292:293-300.

Constantine, N. L., E. Claire, T. Campbell, W.M. Baughman, K.V. Miller. 2015. Small mammal distributions relative to southern pine plantations. Southern Journal of Applied Forestry July:148-151.

Cox, W.A., F.R. Thompson, and J. Faaborg. 2012. Landscape forest cover and edge effects on songbird nest predation vary by nest predator. Landscape Ecology 27(5):659-669.

Cristan, R., W. M. Aust, M. C., Bolding, S. M. Barrett, J. F. Munsell, and E. Schilling. 2016. Effectiveness of forestry best management practices in the United States: Literature review. Forest Ecology and Management 360:133-151.

Daily, G. C., S. Polasky, J. Goldstein, P. M. Kareiva, H. A. Mooney, L. Pejchar, T. H. Ricketts, J. Salzman, and R. Shallenberger. 2009. Ecosystem services in decision making: Time to deliver. Frontiers in Ecology and the Environment 7(1) 21-28

DeBell, D.S., R.O.Curtis, C.A. Harrington, and J.C. Tappeiner. 1997. Shaping stand development through silvicultural practices. Pages 141-149 in K.A. Kohm and J.F. Franklin, eds. Island Press. Washington, DC.

Dellasala, D. A., J.C. Hagar, K.A. Engel, W.C. McComb, R.L. Fairbanks, and E.G. Campbell. 1996. Effects of silvicultural modifications of temperate rainforest on breeding and wintering bird communities, Prince of Wales Island, southeast Alaska. The Condor 98(4):706-721.

deMaynadier, P. G., and M.L. Hunter Jr. 1995. The relationship between forest management and amphibian ecology: a review of the North American literature. Environmental Reviews 3(3-4): 230-261.

deMaynadier, P. G., and M.L. Hunter. 1998. Effects of silvicultural edges on the distribution and abundance of amphibians in Maine. Conservation Biology 12(2):340-352. 


\section{DRAFT Terrestrial Vertebrate Biodiversity and IFM in the U S}

Dickson, J. G. 2001. Wild turkey. Pages 108-121 in J. G. Dickson, editor. Wildlife of southern forests, habitat and management. Hancock House Publishers, Blaine, Washington, USA.

Dickson, J.G., J.H. Williamson. 1988. Small mammals in streamside management zones in pine plantations. In: Szaro, R.C., Severson, K.E., Patton. D.R. (Technical coordinators). Proceedings of the Symposium on Management of Amphibians, Reptiles. and Small Mammals in North America. General Technical Report RM-166. United States Forest Service, pp. 375-378.

Duguay, J. P., P.B. Wood, and G.W. Miller. 2000. Effects of timber harvests on invertebrate biomass and avian nest success. Wildlife Society Bulletin, 28(4):1123-1131.

Duvall, D., and D.I.F. Grigal. 1999. Effects of timber harvesting on coarse woody debris in red pine forests across the Great Lakes states, U.S.A. Canadian Journal of Forest Research 29: $1926-1934$.

Ellis, T. M. and M. G. Betts. 2011. Bird abundance and diversity across a hardwood gradient within early seral plantation forest. Forest Ecology and Management, 261(8): 13721381.

Elmore, L. W., D. A. Miller, and F. J. Vilella. 2004. Selection of diurnal roosts by red bats (Lasiurus borealis) in an intensively managed pine forest in Mississippi. Forest Ecology and Management 199:11-20.

Enge, K. M., and W.R. Marion. 1986. Effects of clearcutting and site preparation on herpetofauna of a North Florida flatwoods. Forest Ecology and Management, 14(3):177192.

Escobar, M.A.H., S.V. Uribe, R. Chiappe, and C.F. Estades. 2015. Effect of clearcutting operations on the survival rate of a small mammal. PLOS ONE 10(3):e0118883.

Etterson, M.A., R. Greenberg, and T. Hollenhorst. 2014. Landscape and regional context differentially affect nest parasitism and nest predation for wood thrush in central Virginia, USA. Condor 116(2):205-214.

Fahrig, L. 2003. Effects of habitat fragmentation on biodiversity. Annual Review of Ecology, Evolution, and Systematics 34(1):487-515.

Farrell, C. B. 2013. Response of small mammals to variable retention of woody debris following biomass harvests in the southeast. University of Georgia, Athens, GA, USA.

Food and Agricultural Organization of the United Nations (FAO). 2009. The State of the World's Forests 2009. Food and Agricultural Organization of the United Nations, Rome, Italy. http://www.fao.org/docrep/011/i0350e/i0350e00.HTM. 


\section{DRAFT Terrestrial Vertebrate Biodiversity and IFM in the U S}

Food and Agricultural Organization of the United Nations (FAO). 2010. Global Forest Resources Assessment 2010. Rome, Italy. http://www.fao.org/forestry/fra/fra2010/en/.

Food and Agricultural Organization of the United Nations (FAO). 2015. Global Forest Resources Assessment 2015 - How are the world's forests changing? Food and Agricultural Organization of the United Nations. http://www.fao.org/forest-resources-assessment/en/

Forest Guild. 2013. Forest biomass retention and harvesting guidelines for the Southeast. Forest Guild, Santa Fe, New Mexico, USA.

Fox, T.R. 2000. Sustained productivity in intensively managed forest plantations. Forest Ecology and Management 138:187-202.

Fox, T.R., E.J. Jokela, and H.L. Allen. 2007. The development of intensively managed forest silviculture in the southern United States. Journal of Forestry 105(7):337-347.

Franklin, J.F., D.R. Berg, D.A. Thornburgh, and J.C. Tappeiner. 1997. Alternative silvicultural approaches to timber harvesting variable retention harvest systems. Pages 111-139 in K.A. Kohm and J.F. Franklin, editors. Creating a forestry for the $21^{\text {st }}$ century. Island Press, Washington, DC.

Franklin, J. F., and K.N. Johnson. 2012. A restoration framework for federal forests in the Pacific Northwest. Journal of Forestry 110(8):429-439.

Franzreb, E., and D. Ohmart. 1978. The effects of timber harvesting on breeding birds in a mixed-coniferous forest. Condor 80:431-441.

Fraver, S. 1994. Vegetation Responses along the edge-to-interior gradients in the mixed hardwood forests of the Roanoke River Basin, North Carolina. Conservation Biology $8(3): 822-832$.

Fritts, S. R., S. M. Grodsky, D. W. Hazel, J. A. Homyack, S. B. Castleberry, and C. E. Moorman. 2015. Quantifying multi-scale habitat use of woody biomass by southern toads. Forest Ecology and Management 346:81-88.

Fritts, S. R., C. E. Moorman, D. W. Hazel, and B. D. Jackson. 2014. Biomass harvesting guidelines affect downed woody debris retention. Biomass and Bioenergy 70:382-391.

Fritts, S., C. Moorman, S. Grodsky, D. Hazel, J. Homyack, C. Farrell, and S. Castleberry. $2016 a$. Do biomass harvesting guidelines influence herpetofauna following harvests of logging residues for renewable energy? Ecological Applications, 26(3):926-939.

Fritts, S., C. Moorman, S. Grodsky, D. Hazel, J. Homyack, C. Farrell, and S. Castleberry. 2016b. Do biomass harvesting guidelines influence herpetofauna following harvests of logging residues for renewable energy? Ecological Applications 26:926-939. 


\section{DRAFT Terrestrial Vertebrate Biodiversity and IFM in the U S}

Fuller, A. K., and D.J. Harrison. 2005. Influence of partial timber harvesting on American martens in north-central Maine. The Journal of Wildlife Management 69(2):710-722.

Fuller, A. K., D.J. Harrison, and H.J. Lachowski. 2004. Stand scale effects of partial harvesting and clearcutting on small mammals and forest structure. Forest Ecology and Management 191(1-3):373-386.

Gaines, W., M. Haggard, J. Begley, J. Lehmkuhl, and A. Lyons. 2010. Short-term effects of thinning and burning restoration treatments on avian community composition, density, and nest survival in the eastern Cascades dry forests, Washington. Forest Science 56(1):88-99.

Garman, S. L. 2001. Response of ground-dwelling vertebrates to thinning young stands: the young stand thinning and diversity study. Simulation 1-27.

Glenn-Lewin, D.C., R.K. Peet and T.T. Veblen. 1992. Plant succession: theory and prediction. Springer, New York.

Gram, W. K., P. Porneluzi, R.L. Clawson, J. Faaborg, and S.C. Richter. 2003. Effects of experimental forest management on density and nesting success of bird species in Missouri Ozark Forests. Conservation Biology 17(5):1324-1337.

Graves, G. R. 2014. Recent large-scale colonization of southern intensively managed forests by Swainson's warbler Limnothlypis swainsonii. Bird Conservation International:1-14.

Gray, S.M., A.K. Killion, G.J. Roloff, B.P. Potters, and T.T. Engstrom. 2016. Fine scale correlates of small mammal abundance in industrial forests of northern California. Northwest Science 90(3):301-314.

Greenberg, C.H., D.G. Neary, and L.D. Harris. 1994. Effect of high-intensity wildfire and silvicultural treatments on reptile communities in sand-pine scrub. Conservation Biology 1047-1057.

Greene, R. E., R. B. Iglay, K. O. Evans, D. A. Miller, T. B. Wigley, and S. K. Riffell. 2016. A meta-analysis of biodiversity responses to management of southeastern pine forests opportunities for open pine conservation. Forest Ecology and Management 360:30-39.

Greene, R. E., R. B. Iglay, K. O. Evans, T. B. Wigley, and D. A. Miller. In press. Gopher tortoise (Gopherus polyphemus) habitat conditions in intensively managed pine forests in the southeastern U.S.: a literature review and landscape analysis. Wildlife Society Bulletin.

Grialou, J. A., S.D. West, and R.N. Wilkins. 2000. The effects of forest clearcut harvesting and thinning on terrestrial salamanders. Journal of Wildlife Management 64(1):105-113.

Griffin, P. C., and L.S. Mills. 2007. Precommercial thinning reduces snowshoe hare abundance in the short term. Journal of Wildlife Management 71(2):559-564. 
Grodsky, S. M., C. E. Moorman, S. R. Fritts, D. W. Hazel, J. A. Homyack, S. B. Castleberry, and T. B. Wigley. 2016. Winter bird use of harvest residues in clearcuts and the implications of forest bioenergy harvest in the southeastern United States. Forest Ecology and Management 379:91-101.

Gustafson, E. J., and T.R. Crow. 1994. Modeling the effects of forest harvesting on landscape structure and the spatial distribution of cowbird brood parasitism. Landscape Ecology 9(4):237-248.

Guynn Jr, D. C., S.T. Guynn, T.B. Wigley, and D.A. Miller. 2004. Herbicides and forest biodiversity - what do we know and where do we go from here? Wildlife Society Bulletin, 32(4):1085-1092.

Haeussler, S., L. Bedford, J.O. Boateng, and A. MacKinnon. 1999. Plant community responses to mechanical site preparation in northern interior British Columbia. Canadian Journal of Forest Research, 29(7):1084-1100.

Hagan, J. M., P.S. McKinley, A.L Meehan, and S.L. Grove. 1997. Diversity and abundance of landbirds in a northeastern industrial forest. The Journal of Wildlife Management 61(3):718-735.

Hagar, J. C. 2007. Wildlife species associated with non-coniferous vegetation in Pacific Northwest conifer forests: A review. Forest Ecology and Management 246(1):108-122.

Hagar, J., S. Howlin, and L. Ganio. 2004. Short-term response of songbirds to experimental thinning of young Douglas-fir forests in the Oregon Cascades. Forest Ecology and Management 199(2-3):333-347.

Hammond, P. C., and J. C. Miller. 1998. Comparison of lepidopteran biodiversity within three forest ecosystems. Conservation Biology and Biodiversity 91: 323-328.

Hanberry, B. B., P. Hanberry, S.K. Riffell, S. Demarais, and J.C. Jones. 2012a. Bird assemblages of intensively established pine plantations in coastal plain Mississippi. Journal of Wildlife Management 76(6):1205-1214.

Hanberry, B.B., P. Hanberry, S. Demarais, and J.C. Jones. 2012b. Importance of residual trees to birds in regenerating pine plantations. Iforest-Biogeosciences and Forestry 5:108-112.

Hanberry, B.B., P. Hanberry, S.K. Riffell, and S. Demarais. 2013. Wintering birds in intensively established pine plantations of Coastal Plain Mississippi. Southern Journal of Applied Forestry 37(2):91-96.

Hanselmann, R., and A.E. Jolles. 2012. How intensive forest management affects disease in wildlife: Patterns of Sin Nombre virus infection and gastrointestinal parasitism in wild deer mice (Peromyscus maniculatus). Integrative and Comparative Biology 52:E258. 


\section{DRAFT Terrestrial Vertebrate Biodiversity and IFM in the U S}

Hanski, I. K., T.J. Fenske, and G.J. Niemi. 1996. Lack of edge effect in nesting success of breeding birds in managed forest landscapes. The Auk 113(3):578-585.

Harper, E.B., D.A. Patrick, and J.P. Gibbs. 2015. Impact of forestry practices at a landscape scale on the dynamics of amphibian populations. Ecological Applications 25(8):2271-2284.

Harpole, D. N., and C.A. Haas. 1999. Effects of seven silvicultural treatments on terrestrial salamanders. Forest Ecology and Management 114:349-356.

Harrington, T. B., P.J. Minogue, D.K. Lauer, and W. Ezell. 1998. Two-year development of southern pine seedlings and associated vegetation following spray-and-burn site preparation with imazapyr alone or in mixture with other herbicides. New Forests15(1):89-106.

Harrington, T., and M.B. Edwards. 1996. Structure of mixed pine and hardwood stands 12 years after various methods and intensities of site preparation in the Georgia Piedmont. Canadian Journal of Forest Research 26:1490-1500.

Harris, L. D., L.D. White, J.E. Johnston, and D.G. Milchunas. 1974. Impact of forest plantation on North Florida wildlife and habitat. Proceedings of the Annual Conference of the South East Association of Fish and Wildlife Agencies 28:659-667.

Hartley, M. J., and M.L. Hunter. 1998. A meta-analysis of forest cover, edge effects, and artificial nest predation rates. Conservation Biology 12(2):465-469.

Hedman, C. W., S. L. Grace, S. E. King. 2000. Vegetation composition and structure of coastal plain pine forests: an ecological comparison. Forest Ecology and Management 134:233247.

Hein, C.D., S.B. Castleberry, and K.V. Miller. 2009. Site-occupancy of bats in relation to forested corridors. Forest Ecology and Management 257:1200-1207.

Helms, J.A. (editor). 1998. The dictionary of forestry. The Society of American Foresters. Bethesda, MD. 210pp.

Henry, D. R., D. A. Miller, and T. W. Sherry. 2015. Integrating Wildlife Conservation with Commercial Silviculture - Demography of the Swainson's Warbler (Limnothlypis swainsonii), a Migrant Bird of Conservation Concern in Southern Pine Forests, USA.

Herbeck, L. A. and D.R. Larsen. 1999. Plethodontid salamander response to silvicultural practices in Missouri Ozark forests. Conservation Biology 13(3):623-632.

Hocking, D. J., and R.D. Semlitsch. 2007. Effects of timber harvest on breeding-site selection by gray treefrogs (Hyla versicolor). Biological Conservation 138(3-4):506-513.

Hobson, K.A., and J. Schieck. 1999. Changes in bird communities in boreal mixedwood forest: 


\section{DRAFT Terrestrial Vertebrate Biodiversity and IFM in the U S}

Harvest and wildfire effects over 30 years. Ecological Applications 9(3):849-863.

Hocking, D.J., G.M. Connette, C.A. Conner, B.R. Scheffers, S.E. Pittman, W.W. Peterman, and R.D. Semlitsch. 2013. Effects of experimental forest management on a terrestrial, woodland salamander in Missouri. Forest Ecology and Management 287:32-39.

Homyack, J.A., and C. Haas. 2013. Effects of repeated-stand entries on terrestrial salamanders and their habitat. Southeastern Naturalist 12(2):353-366.

Homyack, J. A., and A. J. Kroll. 2014. Slow lives in the fast landscape: conservation and management of plethodontid salamanders in production forests of the United States. Forests 5:2750-2772

Homyack, J. A., Z. Aardweg, T. A. Gorman, and D. R. Chalcraft. 2013. Initial effects of woody biomass removal and intercropping of switchgrass (Panicum virgatum) on herpetofauna in eastern North Carolina. Wildlife Society Bulletin 1-9.

Homyack J. A., D. J. Harrison, and W. B. Krohn. 2004. Structural differences between precommerically thinned and unthinned conifer stands. Forest Ecology and Management 194:131-143.

Homyack J. A., D. J. Harrison, and W. B. Krohn. 2005. Long-term effects of precommercial thinning on small mammals in northern Maine. Forest Ecology and Management 205:4357.

Homyack J. A., D. J. Harrison, and W. B. Krohn. 2007. Effects of precommercial thinning on snowshoe hares in Maine. Journal of Wildlife Management 71:4-13.

Homyack, J.A. B.J. Paxton, M.D. Wilson, B.D. Watts, and D.A. Miller. 2011. Snags and cavitynesting birds within intensively managed pine stands in eastern North Carolina, USA. Southern Journal of Applied Forestry 35(3):148-154.

Homyack, J.A., Z. Aardweg, T.A. Gorman, and D.R. Chalcraft. 2013. Initial effects of woody biomass removal and intercropping of switchgrass (Panicum virgatum) on herpetofauna in eastern North Carolina. Wildlife Society Bulletin 37(2):327-335.

Homyack, J. A., K. E. Lucia-Simmons, D. A. Miller, and M. Kalcounis-Rueppell. 2014a. Rodent population and community responses to forest-based biofuel production. Journal of Wildlife Management 78:1425-1435.

Homyack, J. A., C. J. O’Bryan, J. E. Thornton, and R. F. Baldwin. 2014b. Anuran assemblages associated with roadside ditches in a managed pine landscape. Forest Ecology and Management 334:217-231. 
Homyack, J. A., C. J. O’Bryan, J. E. Thornton, and R. F. Baldwin. 2016. Community occupancy of herpetofauna in roadside ditches in a managed pine landscape. Forest Ecology and Management 361:346-357.

Homyack, J. A., B. J. Paxton, M. D. Wilson, B. D. Watts, and D. A. Miller. 2011. Snags and cavity-nesting birds within intensively managed pine stands in eastern North Carolina, USA. Southern Journal of Applied Forestry 35:148-154.

Howell, C.A., W.D. Dijak, and F.R. Thompson. 2007. Landscape context and selection for forest edge by breeding brown-headed cowbirds. Landscape Ecology 22(2):273-284.

Hood, S. A., D. A. Miller, B. D. Leopold, and L. W. Burger. 2002. Small mammal and herpetile response to mid-rotation pine management in Mississippi. Proceedings of the Southeastern Association of Fish and Wildlife Agencies 56:171-186.

Howell, C. A., S.C. Latta, T.M. Donovan, P.A. Porneluzi, G.R. Parks, and J. Faaborg. 2000. Landscape effects mediate breeding bird abundance in midwestern forests. Landscape Ecology 15:547-562.

Humphries, W. J. 2005. Relationships between amphibian and reptile communities and forest management in upland pine stands of the South Carolina coastal plain. Clemson University, Clemson, South Carolina, USA.

Hurst, G. A., and R. C. Warren. 1982. Deer forage in 13-year-old commercially thinned and burned loblolly intensively managed forests. Proceedings of the Southeastern Association of Fish and Wildlife Agencies 36:420-426.

Hurst, G. A., L. M. Wilson, B. D. Leopold, R. M. Watkins, and M. D. Weinstein. 1994. Plant species richness following chemical and mechanical site preparation in Mississippi. Proceedings of environmental issues affecting the forestry and forest products industries in the Eastern United States. US Forest Service, General Technical Report NE-219, Washington, D.C., USA 131-133.

Huston, M.A. 1999. Forest productivity and diversity: Using ecological theory and landscape models to guide sustainable forest management. Rocky Mountain Research Station USFS, Guadalajara, Mexico, pp. 329-341.

Iglay, R. B. 2010. Effects of prescribed fire and selective herbicide (Imazapyr) on biodiversity in intensively managed pine stands of Mississippi. Mississippi State University, Mississippi State, Mississippi, USA.

Iglay, R. B., B. D. Leopold, D. A. Miller, and L. W. Burger, Jr. 2010. Effects of plant community composition on plant response to fire and herbicide treatments. Forest Ecology and Management 260:543-548. 
Iglay, R. I., P. D. Jones, D. A. Miller, S. Demarais, B. D. Leopold, and L. W. Burger, Jr. 2010. Deer carrying capacity in mid-rotation intensively managed forests of Mississippi. Journal of Wildlife Management 74:1003-1012.

Iglay, R. I., S. K. Riffell, D. A. Miller, and B. D. Leopold. 2012a. Effects of switchgrass intercropping and biomass harvesting on plant communities in intensively managed pine stands. Proceedings from the Sun Grant National Conference: science for biomass feedstock production and utilization:Paper 3.6.

Iglay, R. B., S. Demarais, T. B. Wigley, and D. A. Miller. 2012b. Bird community dynamics and vegetation relationships among stand establishment practices in intensively managed pine stands. Forest Ecology and Management, 283, 1-9.

Iglay, R. B., D. A. Miller, B. D. Leopold, and G. Wang. 2012c. Carabid beetle response to prescribed fire and herbicide in intensively managed, mid-rotation pine stands in Mississippi

Iglay, R. B., B. D. Leopold, and D. A. Miller. 2014a. Summer herpetofaunal response to prescribed fire and herbicide in intensively managed, mid-rotation pine stands in Mississippi. Wildlife Society Bulletin 38:33-42.

Iglay, R. B., B. D. Leopold, and D. A. Miller. 2014b. Vegetation responses to fire and herbicide in intensively managed, mid-rotation pine. Forest Ecology and Management 328:69-78.

International Union for Conservation and Nature (IUCN). 2010. Plants under pressure - a global assessment. The First Report of the IUCN Sampled Red List Index for Plants. Royal Botanic Gardens, Kew, UK; Natural History Museum, London, England.

Irwin, L. L., D.F. Rock, S.C. Rock, C. Loehle, and P. Van Deusen. 2015. Forest ecosystem restoration: initial response of spotted owls to partial harvesting. Forest Ecology and Management 354:232-242.

Ivan, J.S., G.C. White, and T.M. Shenk. 2014. Density and demography of snowshoe hares in central Colorado. Journal of Wildlife Management 78(4): 580-594.

Jeffries, S. B., T. R. Wentworth, and Allen, H. L. 2010. Long-term effects of establishment practices on plant communities across successive rotations in a loblolly pine (Pinus taeda) plantation. Forest Ecology and Management 260:1548-1556.

Johnson, W. N., Jr., and P. W. Brown. 1990. Avian use of a lakeshore buffer strip and an undisturbed lakeshore in Maine. Northern Journal of Applied Forestry 7:114-117.

Johnson, A. S., and J.L. Landers. 2015. Habitat relationships of summer resident birds in slash pine flatwoods. Journal of Wildlife Management 46(2):416-428.

Johnson, B. A., J. A. Homyack, K. Barrett, and R. F. Baldwin. 2016. Factors influencing herpetofaunal assemblages of aquatic systems in a managed pine forest. Forest Ecology 


\section{DRAFT Terrestrial Vertebrate Biodiversity and IFM in the U S}

and Management 379:124-132.

Johnson, D.H., and T.A. O’Neil. 2001. Wildlife-habitat relationships in Oregon and Washington. Oregon State University Press, Corvallis, Oregon, USA.

Jokela, E.J., T.A. Martin, and J.G. Vogel. 2010. Twenty five years of intensive forest management with southern pines: Important lessons learned. Journal of Forestry 2010:338-347.

Jones, J.E., A.J. Kroll, J. Giovanini, S.D. Duke, T.M. Ellis, and M.G. Betts. 2012a. Avian species richness in relation to intensive forest management practices in early seral tree plantations. PLOS ONE 7(8): e43290. doi:10.1371/journal.pone.0043290

Jones, P., L.W. Burger Jr, and S. Demarais. 2010. Habitat value of intensively established pine plantations for northern bobwhite. The Journal of Wildlife Management 74(3): 449-458.

Jones, J. C., and B. Dorr. 2004. Habitat associations of gopher tortoise burrows on industrial timberlands. Wildlife Society Bulletin 32:456-464.

Jones, P., B. Hanberry, and S. Demarais. 2008. Biodiversity response to stand structure features in southern pine forests: A literature review. National Council for Air and Stream Improvement Technical Bulletin No. 958:67.

Jones, P. D., S.L. Edwards, S. Demarais, and A.W. Ezell. 2009a. Vegetation community responses to different establishment regimes in loblolly pine (Pinus taeda) plantations in southern Mississippi, USA. Forest Ecology and Management 257(2):553-560.

Jones P. D., S. Demarais, A.W. Ezell. 2012. Successional trajectory of loblolly pine (Pinus taeda) plantations established using intensive management in Southern Mississippi, USA. Forest Ecology and Management 265:116-123.

Jones, P., S.L. Edwards and S. Demarais. 2009a. White-tailed deer foraging habitat in intensively established loblolly pine plantations. The Journal of Wildlife 73(4):488-496.

Jones, P. D., M. R. Mixon, and S. Demarais. 2009b. Habitat quality following mid-rotation treatment in conservation reserve program pines. Journal of Wildlife Management 73:1166-1173.

Jones, J. C., D. A. Miller, N. B. Hodges, and A. W. Posner. 2016. Herpetofaunal and vegetation communities in protected coves and managed intensively managed forests of an industrial forest in north-central Mississippi. Journal of the Southeastern Association of Fish and Wildlife Agencies 3:in press.

Jones, J. and M. J. Chamberlain. 2004. Efficacy of herbicides and fire to improve vegetative conditions for northern bobwhite in mature pine forests. Wildlife Society Bulletin 32:1077-1084. 


\section{DRAFT Terrestrial Vertebrate Biodiversity and IFM in the U S}

Jules, E. S., E.J. Frost, L.S. Mills, and D.A. Tallmon. 1999. Ecological consequences of forest fragmentation in the Klamath region. Natural Areas Journal 19(4):368-378.

Kalcounis-Rueppell, M. C., K.M. Briones, J.A. Homyack, R. Petric, M.M. Marshall, and D.A. Miller. 2013. Hard forest edges act as conduits, not filters, for bats. Wildlife Society Bulletin 37(3):571-576.

Karraker, N. E., and Welsh, H. H. 2006. Long-term impacts of even-aged timber management on abundance and body condition of terrestrial amphibians in Northwestern California. Biological Conservation 131(1):132-140.

Karriker, K. S. 1996. Effects of intensive silviculture on breeding and wintering birds in North Carolina pocosins. National Council of the Paper Industry for Air and Stream Improvement, Inc., Research Triangle Park, North Carolina, USA.

Kellner, K.F., N.A. Urban, and R.K. Swihart. 2013. Short-term responses of small mammals to timber harvest in the United States Central Hardwood Forest Region. Journal of Wildlife Management 77(8):1650-1663.

Kendrick, S.W., P.A. Porneluzi, F.R. Thompson, D.L. Morris, J.M. Haslerig, and J. Faaborg. 2015. Stand-level bird response to experimental forest management in the Missouri Ozarks. Journal of Wildlife Management 79(1):50-59.

Keyser, A. J. 2002. Nest predation in fragmented forests: landscape matrix by distance from edge interactions. The Wilson Bulletin 114(2):186-191.

Kilgo, J., K. Miller, and W. Moore. 2000. Coordinating short-term projects into an effective research program: effects of site preparation methods on bird communities in pine plantations. Studies in Avian Biology 21(21):144-147.

King, D. I., and S. Schlossberg. 2013. Synthesis of the conservation of the early-successional stages in forests of eastern North America. Forest Ecology and Management 324:186-195

King, K. L., J. A. Homyack, T. B. Wigley, Jr., D. A. Miller, and M. C. Kalcounis-Rueppell. 2014. Response of rodent community structure and population demographics to intercropping switchgrass within loblolly intensively managed forests in a forestdominated landscape. Biomass and Bioenergy 69:255-264.

Kirkland, G.L. 1990. Patterns of initial small mammal community change after clearcutting of temperate North American forests. Oikos 59(3):313-320.

Kirkland, G. L., T.R. Johnston, P.F. Steblein, Jr, T.R.J. Johnston. 1985. Small mammal exploitation of a forest-clearcut interface. Theriologica 30(11):211-218.

Knapp, S. M., C.A. Haas, D.N. Harpole, and R.L. Kirkpatrick. 2003. Initial effects of clearcutting and alternative silvicultural practices on terrestrial salamander abundance. 


\section{DRAFT Terrestrial Vertebrate Biodiversity and IFM in the U S}

Conservation Biology 17(3):752-762.

Kroll, A.J. 2009. Sources of uncertainty in stream-associated amphibian ecology and responses to forest management in the Pacific Northwest, USA: A review. Forest Ecology and Management 257(4):1188-1199.

Kroll, A.J., K. Risenhoover, T. McBride, E. Beach, B.J. Kernohan, J. Light, and J. Bach. 2008. Factors influencing stream occupancy and detection probability parameters of streamassociated amphibians in commercial forests of Oregon and Washington, USA. Forest Ecology and Management 255(11):3726-3735.

Kroll, A. J., S. D. Duke, M. E. Hane, J. R. Johnson, M. Rochelle, M. G. Betts and E. B. Arnett. 2012a. Landscape composition influences avian colonization of experimentally created snags. Biological Conservation 152:145-51.

Kroll, A. J., M. J. Lacki, and E. B. Arnett. 2012b. Research needs to support management and conservation of cavity-dependent birds and bats on forested landscapes of the Pacific Northwest. Western Journal of Applied Forestry 27:128-136.

Kroll, A. J., Y. Ren, J. E. Jones, J. Giovanini, R. W. Perry, R. E. Thill, D. White, Jr., and T. B. Wigley. 2014. Avian community composition associated with interactions between local and landscape habitat attributes. Forest Ecology and Management 326:46-57.

Lang, A., S. Baker, and B. Mendell. 2016. Forest management practices of private timberland owners and managers in the U.S. South (2016 Update). Technical Release 16-R-17. Forest Resources Association, Inc. Rockville, MD. http://forestoperationsreview.org/technical-releases/

Lane, V. R., K.V. Miller, S.B. Castleberry, R.J. Cooper, D.A. Miller, T.B. Wigley, and R.L. Mihalco. 2011. Bird community responses to a gradient of site preparation intensities in pine plantations in the Coastal Plain of North Carolina. Forest Ecology and Management 262(9):1668-1678.

Lantschner, M., V. Rusch, and J.P. Hayes. 2011. Influences of pine plantations on small mammal assemblages of the Patagonian forest-steppe ecotone. Mammalia 75(3):249-255.

Larsen, A. L., J. A. Homyack, T. B. Wigley, D. A. Miller, and M. C. Kalcounis-Rueppella. 2016. Effects of habitat modification on cotton rat population dynamics and rodent community structure. Forest Ecology and Management 376:238-246.

Lauer, D. K., and B.R. Zutter. 2001. Vegetation cover response and second-year loblolly and slash pine response following bedding and pre- and post-plant herbicide applications in Florida. Southern Journal of Applied Forestry 25(2):75-83.

Law, B., K. J. Park, and M. J. Lacki. 2016. Insectivorous bats and silviculture: balancing timber production and bat conservation. Pages 105 - 150 in C. C. Voigt and T. Kingston, 


\section{DRAFT Terrestrial Vertebrate Biodiversity and IFM in the U S}

eds. Bats in the Anthropocene: conservation of bats in a changing world. DOI 10.1007/978-3-319-25220-9_5.

Leblond, M., C. Dussault, and M.H. St-Laurent. 2015. Low-density spruce plantations increase foraging by moose in a northeastern temperate forest. Forest Ecology and Management $347: 228-236$.

Le Roux, D.S., K. Ikin, D.B. Lindemayer, G. Bistricer, A.D. Manning, and P. Gibbons. 2016 Effects of entrance size, tree size and landscape context on nest box occupancy: Considerations for management and biodiversity offsets. Forest Ecology and Management 366:135-142.

Lehmkuhl, J., W. Gaines, D. Peterson, J. Bailey, and A. Youngblood. 2015. Silviculture and monitoring guidelines for integrating restoration of dry mixed-conifer forest and spotted owl habitat management in the eastern Cascade Range. General Technical Report PNWGTR-915:158

Linden, D. W. and G. J. Roloff. 2015. Improving inferences from short-term ecological studies with Bayesian hierarchical modeling: white-headed woodpeckers in managed forests. Ecology and Evolution 5(16): 3378-3388.

Linden, D.W., G.J. Roloff, and A.J. Kroll. 2012. Conserving avian richness through structure retention in managed forests of the Pacific Northwest, USA. Forest Ecology and Management 284:174-184.

Lindenmayer, D.B., and J.F. Franklin 2002. Conserving forest biodiversity: a comprehensive multi-scaled approach. Island Press, Washington D.C.

Lindenmayer, D.B., J.F. Franklin, and J. Fischer. 2006. General management principles and a checklist for strategies to guide forest biodiversity conservation. Biological Conservation 131(3): 433-445.

Lindenmayer, D.B., J.T. Wood, R.B. Cunningham, M. Crane, C. Macgregor, D. Michael, and R. Montague-Drake. 2009. Experimental evidence of the effects of a changed matrix on conserving biodiversity within patches of native forest in an industrial plantation landscape. Landscape Ecology 24(8):1091-1103.

Lindgren, P. M. F., and T. P. Sullivan. 2001. Influence of alternative vegetation management treatments on conifer plantation attributes: Abundance, species diversity, and structural diversity. Forest Ecology and Management, 142(1-3), 163-182.

Lindgren, P. M. F., and T.P. Sullivan. 2013. Long-term responses of tree and stand growth of young lodgepole pine to pre-commercial thinning and repeated fertilization. Forest Ecology and Management 307:155-164.

Loeb, S.C. 1996. The role of coarse woody debris in the ecology of southeastern mammals. 


\section{DRAFT Terrestrial Vertebrate Biodiversity and IFM in the U S}

Pages 1108-1118 in J.W. McMinn, and D.A. Crosslet, Jr., editors. Biodiversity and coarse woody debris in southern forests. USDA Forest Service General Technical Report SE-94.

Loeb, S.C. 1999. Responses of small mammals to coarse woody debris in a southeastern pine forest. Journal of Mammalogy 80(2):460-471.

Loeb, S. C., and T. A. Waldrop. 2008. Bat activity in relation to fire and fire surrogate treatments in southern pine stands. Forest Ecology and Management 255:3185-3192.

Loehle, C., J.G. MacCracken, D. Runde, and L. Hicks. 2002. Forest management at landscape scales: Solving problems. Journal of Forestry 100(6):25-33.

Loehle, C., T.B. Wigley, S. Rutzmoser, J.A. Gerwin, P.D. Keyser, R.A. Lancia, and P.B.Wood. 2005a. Managed forest landscape structure and avian species richness in the southeastern US. Forest Ecology and Management 214(1-3):279-293.

Loehle, C., T.B. Wigley, P.A. Shipman, S.F. Fox, S. Rutzmoser, R.E. Thill, and M.A. Melchiors. 2005b. Herpetofaunal species richness responses to forest landscape structure in Arkansas. Forest Ecology and Management 209:293-308.

Loehle, C., L. Irwin, B.F.J. Manly, and A. Merrill. 2015. Range-wide analysis of northern spotted owl nesting habitat relations. Forest Ecology and Management 342:8-20.

Lohr, A.M., S.A. Gauthreaux, and J.C. Kilgo. 2002. Importance of coarse woody debris to avian communities in loblolly pine forests. Conservation Biology 16(3): 767-777.

Loman, Z. G., S. K. Riffell, D. A. Miller, J. A. Martin, and F. J. Vilella. 2013. Site preparation for switchgrass intercropping in loblolly intensively managed forests reduces retained trees and snags, but maintains downed woody debris. Forestry:1-8.

Loman, Z. G., S. K. Riffell, B. R. Wheat, D. A. Miller, J. A. Martin, and F. J. Vilella. 2014. Breeding bird community response to establishing intercropped switchgraass in intensively-managed pine stands. Biomass and Bioenergy 67:201-211.

Lowery, R. F., and D. H. Gjerstad. 1991. Chemical and mechanical site preparation. Pages 251261 in Forest regeneration manual, Duryea, M.L., and P.M. Dougherty (eds.). Kluwer Academic Publishers, Dordrecht, The Netherlands.

Lubowski, R. N., A. J. Plantinga, and R. N. Stavins. 2008. What drives land-use change in the United States? A national analysis of landowner decisions. Land Economics 84(4):529550.

Lycke, A., L. Imbeau, and P. Drapeau. 2011. Effects of commercial thinning on site occupancy and habitat use by spruce grouse in boreal Quebec. Canadian Journal of Forest Research 41(3):501-508. 
Maine Forest Service. 2014. 2014 silvicultural activities report. Department of Agriculture, Conservation and Forestry, Maine Forest Service, Forest Policy and Management Division. Augusta, ME. http://www.maine.gov/dacf/mfs/publications/annual_reports.html

Mainwaring, D. B., D.A. Maguire, A. Kanaskie, and J. Brandt. 2005. Growth responses to commercial thinning in Douglas-fir stands with varying severity of Swiss needle cast in Oregon, USA. Canadian Journal of Forest Research 35:2394-2402.

Major, M., and A. Desrochers. 2013. Wildlife-mitigated precommercial thinning maintains the abundance of fruit shrubs in a boreal forest. Canadian Journal of Forest Research 43(3):306-310.

Manning, T., J.C. Hagar, and B.C. McComb. 2012. Thinning of young Douglas-fir forests decreases density of northern flying squirrels in the Oregon Cascades. Forest Ecology and Management, 264, 115-124. http://doi.org/10.1016/j.foreco.2011.09.043

Marshall, M. M., K. E. Lucia, J. A. Homyack, D. A. Miller, and M. C. Kalcounis-Rueppell. 2012. Effect of removal of woody biomass after clearcutting and intercropping switchgrass (Panicum virgatum) with loblolly pine (Pinus taeda) on rodent diversity and populations. International Journal of Forestry Research 2012.

Marshall, C. D. 2016. Assessment of early successional arthropod and breeding bird response to intercropping switchgrass within an intensively managed loblolly pine forests. Thesis. Department of Wildlife, Fisheries, and Aquaculture, Mississippi State University, Mississippi State, Mississippi, USA.

Marshall, M.R., J.A. DeCecco, A.B. Williams, G.A. Gale, and R.J. Cooper. 2003. Use of regenerating clearcuts by late-successional bird species and their young during the postfledging period. Forest Ecology and Management 183:127-135.

McDermott, M.E., P.B. Wood, G.W. Miller, and B.T. Simpson. 2011. Predicting breeding bird occurrence by stand- and microhabitat-scale features in even-aged stands in the Central Appalachians. Forest Ecology and Management 261(3):373-380.

McShea, W. J., W. M. Healy, and P. Van Deusen. 2015. Trends in mast availability for wild turkeys in eastern forests. Proceedings of the National Wild Turkey Symposium 11:6178

McWethy, D. B., A.J. Hansen, and J. P. Verschuyl. 2009. Edge effects for songbirds vary with forest productivity. Forest Ecology and Management 257(2):665-678.

McWethy, D. B., A.J. Hansen, and J. P. Verschuyl. 2010. Bird response to disturbance varies with forest productivity in the northwestern United States. Landscape Ecology 25(4):533-549. 
DRAFT Terrestrial Vertebrate Biodiversity and IFM in the U S

Millenium Ecosystem Assessment. 2005. Ecosystems and Human Well-being: Biodiversity Synthesis. World Resources Institute, Washington, DC.

Meggs, J.M. 2009. Wildlife responses to stand-level structural retention practices in the boreal forest. National Council for Air and Stream Improvement Technical Bulletin No. 964. $115 \mathrm{pp}$.

Mendell, B. C., A. H. Lang, W. Caldwell, and D. L. Garrett. 2015. Chemical use and forest certification: productivity and economic implications. Journal of Forestry 113:367-371.

Miles, A. C., S. B. Castleberry, D. A. Miller, and L. M. Conner. 2006. Multi-scale roost-site selection by evening bats on pine-dominated landscapes in southwest Georgia. Journal of Wildlife Management 70:1191-1199.

Miller, D. A., and M.J. Chamberlain. 2008. Plant community response to burning and herbicide site preparation in eastern Louisiana, USA. Forest Ecology and Management, 255(3-4), 774-780.

Miller, D. A., and L. M. Conner. 2007. Habitat selection of female turkeys in a managed pine landscape in Mississippi. Journal of Wildlife Management 71:744-751.

Miller, D. A., R.E. Thill, M.A. Melchiors, T.B. Wigley, and P.A. Tappe. 2004. Small mammal communities of streamside management zones in intensively managed pine forests of Arkansas. Forest Ecology and Management 203:381-393.

Miller, D.A., T.B. Wigley, and K.V. Miller. 2009. Managed forests and conservation of terrestrial biodiversity in the southern United States. Journal of Forestry 107(4):197-203.

Miller, K. V, and J.H. Miller. 2004. Forestry herbicide influences on biodiversity and wildlife habitat in southern forests. Wildlife Society Bulletin 32(4):1049-1060.

Mills, L. S. 1995. Edge Effect and Isolation: Red-Backed Voles on Forest Remnants. Conservation Biology 9(2):395-403.

Miner, R. A., R. C. Abt, J. L. Bowyer, M. A. Buford, R. W. Malmsheimer, J. O’Laughlin, E. E. Oneil, R. A. Sedjo, and K. E. Skog. 2014. Forest carbon accounting considerations in US bioenergy policy. Journal of Forestry 112(6):591-606.

Mitchell, M. S., K.S. Karriker, E.J. Jones, and R.A. Lancia. 1995. Small mammal communities associated with pine plantation management of pocosins. Journal of Wildlife Management 59(4):875-881.

Mitchell, M. S., S. H. Rutzmoser, T. B. Wigley, C. Loehle, J. A. Gerwin, P. D. Keyser and P.B. Wood. 2006. Relationships between avian richness and landscape structure at multiple scales using multiple landscapes. Forest Ecology and Management 221(1-3):155-169. 


\section{DRAFT Terrestrial Vertebrate Biodiversity and IFM in the U S}

Morris, A. D., D.A. Miller, and M. C. Kalcounis-Rueppell. 2010. Use of Forest Edges by Bats in a Managed Pine Forest Landscape. The Journal of Wildlife Management 74(1):26-34.

Morrison, M. L., and E. C. Meslow. 1984a. Response of avian communities to herbicide-induced vegetation changes. The Journal of Wildlife Management 48(1):14-22.

Morrison, M.L., and E.C. Meslow. 1984b. Effects of the herbicide glyphosate on bird community structure, western Oregon. Forest Science 30:95-106.

National Association of State Foresters. (NASF). 2015. Protecting water quality through state forestry best management practices. National Association of State Foresters. 8pp. http://stateforesters.org/state-forestry-BMPs-map

Rochelle, J.A.. 2008. The biological basis for forest practices rules for retaining coarse woody debris in managed forests of the Pacific Northwest. Technical Bulletin Number 954, National Council for Air and Stream Improvement, Inc. Research Triangle Park, North Carolina, USA.

Neill, A.R., and K.J. Puettmann. 2013. Managing for adaptive capacity: Thinning improves food availability for wildlife and insect pollinators under climate change conditions. Canadian Journal of Forest Research 43(5): 428-440.

Neu, J., P.D. Jones, S. Demarais, A.W. Ezell, S.K. Riffell, and T.B. Wigley. 2014. Retained woody structure in 1- to 2-year-old loblolly pine (Pinus taeda L.) plantations in Mississippi, Louisiana, and Arkansas: implications for wildlife conservation. Journal of Sustainable Forestry 33(2):152-172.

Newmaster, S. G., W. C. Parker, F. W. Bell, and J. M. Paterson. 2007. Effects of forest floor disturbances by mechanical site preparation on floristic diversity in a central Ontario clearcut. Forest Ecology and Management 246(2-3):196-207.

Newton, M., and L.A. Norris. 1968. Herbicide residues in blacktail deer from forests treated with 2,4,5-T and atrazine. Proceedings of the Western Society of Weed Science 22:32-34.

O’Bryan, C. J., J. A. Homyack, R. F. Baldwin, Y. Kanno, and A. L. Harrison. 2016. Novel habitat use supports population maintenance in a reconfigured landscape. Ecosphere 7(3)e01228:1-15.

O'Connell, W. E., and K.V. Miller. 1994. Site preparation influences on vegetative composition and avian and small mammal communities in the South Carolina Upper Coastal Plain. Proceedings of the Annual Conference for Southeast Association of Fish and Wildlife Agencies 48:321-330.

Oliver, C.D., and B.C. Larson. 1996. Forest stand dynamics, updated edition. John Wiley and Sons, Incorporated. Hoboken New Jersey. 


\section{DRAFT Terrestrial Vertebrate Biodiversity and IFM in the U S}

Olson, D. H., and C. Rugger. 2007. Preliminary study of the effects of headwater riparian reserves with upslope thinning on stream habitats and amphibians in Western Oregon. Forest Science 53(2):331-342.

Oswalt, S.N., W.B. Smith, P.D. Miles, and S.A. Pugh. 2014. Forest resources of the United States, 2012: A technical document supporting the Forest Service update of the 2010 RPA Assessment. USDA Forest Service, General Technical Report WO-91.

Otto, C.R.V., and G.J. Roloff. 2012. Songbird response to green-tree retention prescriptions in clearcut forests. Forest Ecology and Management 284: 241-250.

Otto, C.R.V., A.J. Kroll, and H.C. McKenny. 2013. Amphibian response to downed wood retention in managed forests: A prospectus for future biomass harvest in North America. Forest Ecology and Management 304:275-285.

Otto, C.R.V., G.J. Roloff, and R.E. Thames. 2014. Comparing population patterns to processes: Abundance and survival of a forest salamander following habitat degradation. PloS ONE 9(4): e93859.

Payn, T., J.M. Carnus, P. Freer-Smith, M. Kimberley, W. Kollert, S. Liu, C. Orazio, L. Rodriguez, L. N. Silva, M. J. Wingfield. 2015. Changes in planted forests and future global implications. Forest Ecology and Management 352:57-67.

Pearson, H. A., G.L. Wolters, R.E. Thill, A. Martin Jr., and V.C. Baldwin. 1995. Plant response to soils, site preparation, and initial pine planting density. Journal Of Range Management 48(November):511-516.

Pearson, S.F., J. Giovanini, J.E. Jones, and A.J. Kroll. 2015. Breeding bird community continues to colonize riparian buffers ten years after harvest. PLOS ONE 10(12): e0143241.

Perry, R.W., R.E. Thill, and D. M. Leslie, Jr. 2008. Scale-dependent effects of landscape structure and composition on diurnal roost selection by forest bats. Journal of Wildlife Management 72:913-925.

Petranka, J.W., M.P. Brannon, M.E. Hopey, and C.K. Smith. 1994. Effects of timber harvesting on low elevation populations of southern Appalachian salamanders. Forest Ecology and Management 67:135-147.

Posner, A. W. 2012. Bird, plant, and herpetofaunal associations in cove forests and plantations in Mississippi. Thesis. Department of Wildlife, Fisheries and Aquaculture, Mississippi State University, Mississippi State, Mississippi, USA.

Powell, J.S.V., and K.J. Babbitt. 2015. Despite buffers, experimental forest clearcuts impact amphibian body size and biomass. PLOS ONE 10(11):e0143505. 
Ransome, D. B., P. M. F. Lindgren, D. S. Sullivan, and T. P. Sullivan. 2004. Long-term responses of ecosystem components to stand thinning in young lodgepole pine forest. Population dynamics of northern flying squirrels and red squirrels. Forest Ecology and Management 202(1-3):355-367.

Raybuck, A.L., C.E. Moorman, C.H. Greenberg, C.S. DePerno, K. Gross, D.M. Simon, and G.S. Warburton. 2012. Short-term response of small mammals following oak regeneration silvicultural treatments. Forest Ecology and Management 274:10-16.

Raymond, L. R., and L. M. Hardy. 1991. Effects of a clearcut on a population of the Mole salamander, Ambystoma talpoideum, in an adjacent unaltered forest. Society for the Study of Amphibians and Reptiles 25(4):509-512.

Reukema, D. L. 1975. Guidelines for pre-commercial thinning of Douglas-fir. USDA Forest Service General Technical Report PNW-30:1-16.

Rice, P.M., J.C. Toney, D.J. Bedunah, and C.E. Carlson. 1997. Plant community diversity and growth form responses to herbicide applications for control of Centaurea maculosa. Journal of Applied. Ecology 34: 13971412.

Ries, L., R. J. Fletcher, J. Battin, and T. D. Sisk. 2004. Ecological responses to habitat edges: mechanisms, models, and variability explained. Annual Review of Ecology, Evolution, and Systematics 35(1):491-522.

Ries, L., and T. D. Sisk. 2004. A predictive model of edge effects. Ecology 85(11):2917-2926.

Riffell, S., J. P. Verschuyl, D. A. Miller, and T. B. Wigley. 2011. Biofuel harvests, coarse woody debris, and biodiversity - a meta-analysis. Forest Ecology and Management 261:878-887.

Riffell, S., J. P. Verschuyl, D. A. Miller, and T. B. Wigley, Jr. 2012. Potential biodiversity response to intercropping herbaceous biomass crops on forest lands. Journal of Forestry 110:42-47.

Rosenberg, D. M., H. V. Danks, and D. M. Lemkuhl. 1986. Importance of insects in environmental impact assessment. Environmental Management 10:773-783.

Rosenvalda, R., and A. Lõhmus. 2008. For what, when, and where is green-tree retention better than clear-cutting? A review of the biodiversity aspects. Forest Ecology and Management 255:1-15.

Runciman, J.B., and T.P. Sullivan. 1996. Influence of alternative conifer release treatments on habitat structure and small mammal populations in south central British Columbia. Canadian Journal of Forest Resources 26: 20232034.

Russell, K. R., D. C. J. Guynn, and H. G. Hanlin. 2002. Importance of small isolated wetlands for herpetofaunal diversity in managed, young growth forests in the coastal plain of South Carolina. Forest Ecology and Management 163:43-59. 
Russell, K. R., T. B. Wigley, W. M. Baughman, H. G. Hanlin, W. M. Ford. 2004. Responses of Southeastern amphibians and reptiles to forest management: A review. Pages 319-334 in H. M. Rauscher and K. Johnsen, eds. Gen. Tech. Rep. SRS-75. Asheville, NC: U.S. Department of Agriculture, Forest Service, Southern Research Station.

Savidge, J.A. 1978. Wildlife in a herbicide-treated Jeffrey pine plantation in eastern California. Journal of Forestry 76:476478.

Scanlon, J. J., and T.L. Sharik. 1986. Forage energy for white-tailed deer in loblolly pine plantations. Journal of Wildlife Management 2:301-306.

Schieck, J., and S.J. Song. 2006. Changes in bird communities throughout succession following fire and harvest in boreal forests of western North America: Literature review and metaanalyses. Canadian Journal of Forest Research 36(5):1299-1318.

Schmitt, C.B., N.D. Burgess , L. Coad, A. Belokurov, C. Besançon, L. Boisrobert, A. Campbell, L. Fish, D. Gliddon, K. Humphries, V. Kapos, C. Loucks, I. Lysenko, L. Miles, C. Mills, S. Minnemeyer, T. Pistorius, C. Ravilious, M. Steininger, and G. Winkel. 2009. Global analysis of the protection status of the world's forests. Biological Conservation 142(10):2122-2130.

Sedjo, R.A., and D. Botkin. 1997. Using forest plantations to spare natural forests. Environment 39(10):15-20,30.

Semlitsch, R. D., C.A. Conner, D.J. Hocking, A.G. Tracy, E.B. Harper, R.D. Semlitsch, E.B. Harper. 2008. Effects of timber harvesting on pond-breeding amphibian persistence: testing the evacuation hypothesis. Ecological Applications 18(2):283-289.

Semlitsch, R. D., Todd, B. D., Blomquist, S. M., Calhoun, A. J. K., Gibbons, J. W., Gibbs, J. P., ... Rothermel, B. B.

Semlitsch, R. D., B. D. Todd, S. M. Blomquist, A. J. K. Calhoun, J. W. Gibbons, J. P. Gibbs, G. J. Graeter, E. B. Harper, D. J. Hocking, M. L. Hunter Jr., D. A. Patrick, T. A. G. Rittenhouse, and B. B. Rothermel. 2009. Effects of timber harvest on amphibian populations: understanding mechanisms from forest experiments. BioScience, 59(10): 853-862.

Santillo, D.J., P.W. Brown, and D.M. Leslie, Jr. 1989a. Response of songbirds to glyphosateinduced habitat changes on clearcuts. Journal of Wildlife Management 53(1):64-71.

Santillo, D.J., D.M. Leslie, Jr., and P.W. Brown. 1989b. Responses of small mammals and habitat to glyphosate application on clearcuts. Journal of Wildlife Management 53(1):164-172.

Shepard, J.P., J. Creighton, and H. Duzan. 2004. Forestry herbicides in the United States: An overview. Wildlife Society Bulletin 32: 10201027. 
Shipman, P. A., S. F. Fox, R. E. Thill, J. P. Phelps, and D. M. Leslie, Jr. 2004. Reptile communities under diverse forest management in the Ouachita Mountains, Arkansas. Pages 174-182 Ouachita and Ozark Mountains Symposium: Ecosystem Management Research. U.S. Department of Agriculture, Forest Service, Southern Research Station, Asheville, North Carolina, USA.

Siegel, R.B., and D.F. DeSante. 2003. Bird communities in thinned versus unthinned Sierran mixed conifer stands. Wilson Bulletin 115(2):155-165.

Singleton, L.C., B.G. Sladek, L.W. Burger, and I.A. Munn. 2013. Bird community response to mid-rotation management in Conservation Reserve Program pine plantations. Wildlife Society Bulletin 37(1):189-197.

Smith, D. R., G. A. Hurst, J. D. Burk, B. D. Leopold, and M. A. Melchiors. 1990. Use of loblolly intensively managed forests by wild turkey hens in east-central Mississippi. Proceedings of the National Wild Turkey Symposium 6:61-66.

Smith, J.H.G. 1954. The economics of pruning. The Forestry Chronicle 30(2): 197-214, $10.5558 / \mathrm{tfc} 30197-2$

Smith, L.L., R.S. Taylor, and J.M. Howze. 2015. Recommendation for gopher tortoise burrow buffer to avoid collapse from heavy equipment. Journal of Fish and Wildlife Management 6(2): 456-463.

Solecki, R., B. Stein, T. Frische, S. Matezki, J. Wogram, and M. Streloke. 2014. Paradigm shift in the risk assessment of cumulative effects of pesticide mixtures and multiple residues to humans and wildlife: German proposal for a new approach. Journal für Verbraucherschutz und Lebensmittelsicherheit 9(4):329-331.

Soutiere, E. 1979. Effects of timber harvesting on marten in Maine. Journal of Wildlife Management 43(4):850-860.

Spies, T.A., and S.P. Cline. 1988. Coarse woody debris in forests and plantations of coastal Oregon. Pages 5-24 in C. Maser, R.F. Tarrant, J.M. Trappe, and J.F. Franklin, editors. From the forest to the sea: A study of fallen logs, USDA Forest Service General Technical Report PNW-GTR-229.

Stephens, S.S., and M.R. Wagner. 2007. Forest plantations and biodiversity. Journal of Forestry, 105:307-313.

Stransky, J. J., and L.K. Halls. 1976. Browse quality affected by pine site preparation in east Texas. Proceedings of Annual Conference Southeast Association. Fish and Wildlife Agencies 30:507-512.

Stransky, J. J., J.G. Huntley, and W.J. Risner. 1986. Net community production dynamics in the herb-shrub stratum of a loblolly pine-hardwood forest : effects of clearcutting and site 


\section{DRAFT Terrestrial Vertebrate Biodiversity and IFM in the U S}

preparation. Forest Service, General Technical Report.

Strelke, W. K., and J.G. Dickson. 1980. Effect of forest clear-cut edge on breeding birds in East Texas. Journal of Wildlife Management 44(3):559-567.

Suarez, A. V, K.S. Pfennig, and S.K. Robinson. 1997. Nesting success of a disturbancedependent songbird on different kinds of edges. Conservation Biology 11(4):928-935.

Sullivan, T.P. 1996. Influence of forest herbicide on snowshoe hare population dynamics: Reproduction, growth, and survival. Canadian Journal of Forest Resources 26: 112119.

Sullivan, T.P., and D.S. Sullivan. 1979. The effects of glyphosate herbicide on food preference and consumption in black-tailed deer. Canadian Journal of Zoology 57:1406-1412.

Sullivan, T.P., and D.S. Sullivan. 1982. Responses of small-mammal populations to a forest herbicide application in a 20-year-old conifer plantation. Journal of Applied Ecology 19: 95106.

Sullivan, T.P., C. Nowotny, R.A. Lautenschlager, and R.G. Wagner. 1998a. Silvicultural use of herbicide in sub-boreal spruce forest: Implications for small mammal population dynamics. Journal of Wildlife Management 62: 11961206.

Sullivan, T.P., R.G. Wagner, D.G. Pitt, R.A. Lautenschlager, and D.G. Chen. 1998b. Changes in diversity of plant and small mammal communities after herbicide application in subboreal spruce forest. Canadian Journal of Forest Resources 28: 168177.

Sullivan T. P., Sullivan D. S., Lindgren P. M. F., Ransome D. B. 2007. Long-term responses of ecosystem components to stand thinning in young lodgepole pine forest. IV. Relative habitat use by mammalian herbivores. Forest Ecology and Management. 240:32-41.

Sullivan, T.P., D.S. Sullivan, P.M.F. Lindgren, and D.B. Ransome. 2013. Stand structure and small mammals in intensively managed forests: Scale, time, and testing extremes. Forest Ecology and Management 310:1071-1087.

Suzuki, N., and J. Hayes. 2003. Effects of thinning on small mammals in Oregon coastal forests. The Journal of Wildlife Management 67(2):352-371.

Swanson, M. E., J. F. Franklin, R. L. Beschta, C. M. Crisafulli, D. A. DellaSala, R. L. Hutto, D. B. Lindenmayer, and F. J. Swanson 2011. The forgotten stage of forest succession: earlysuccessional ecosystems on forest sites. Frontiers in Ecology and the Environment 9(2):117-125.

Swift, K.I., and F.W. Bell. 2011. What are environmental consequences of using silviculturally effective forest vegetation management treatments? Forestry Chronicle 87(2):201-216.

Swindel, B. F., L.F. Conde, and J.E. Smith. 1983. Plant cover and biomass response to clear- 


\section{DRAFT Terrestrial Vertebrate Biodiversity and IFM in the U S}

cutting, site preparation and planting in Pinus elliotti flatwoods. Science 1421.

Swindel, B. F., J.E. Smith, D.G. Neary, and N.B. Comerford. 1989. Recent research indicates plant community responses to intensive treatment including chemical amendments. Southern Journal of Applied Forestry 13(3):152-156.

Tappe, P.A., R.E. Thill, M.A. Melchiors, and T.B. Wigley. 2004. Breeding bird communities on four watersheds under different forest management scenarios in the Ouachita Mountains of Arkansas. Pages 154-163 in J. M. Guldin, Tech. Comp. Ouachita and Ozark Mountains Symposium: Ecosystem Management Research. USDA Forest Service General Technical Report SRS-74. Asheville, NC.

Tassone, J. 1981. Utility of hardwood leave strips for breeding birds in Virginia's central Piedmont. Master's Thesis. Virginia. Polytechnic Inst. and State University Blacksburg 83pp.

Tews, J., U. Brose, V. Grimm, K. Tielbörger, M.C. Wichmann, M. Schwager, and F. Jeltsch. 2004. Animal species diversity driven by habitat heterogeneity/diversity: The importance of keystone structures. Journal of Biogeography 31:79-92.

Thilenius, J.F., and G.R. Brown. 1976. Effects of 2,4-D on digestibility and production of subalpine herbage. Journal of Range Management 29:63-65.

Tilghman, J.M., S.W. Ramee, and D.M. Marsh. 2012. Meta-analysis of the effects of canopy removal on terrestrial salamander populations in North America. Biological Conservation 152:1-9.

Tittler, R., E. Filotas, J. Kroese, C. Messier. 2015. Maximizing conservation and production with intensive forest management: it's all about location. Environmental Management 56(5):1104-1117.

Triquet, A. M., G. A. McPeek, and W. C. McComb. 1990. Songbird diversity in clearcuts with and without a riparian buffer strip. Journal of Soil and Water Conservation 45(4):500503.

Tscharntke, T., J.M. Tylianakis, T.A. Rand, R.K. Didham, L. Fahrig, P. Batáry, J. Bengtsson, Y. Clough, T.O. Crist, C.F. Dormann, R.M. Ewers, J. Fründ, R.D. Holt, A. Holzschuh, L.M. Klein, D. Kleijn, C. Kremen, D.A. Landis, W. Laurance, D. Lindenmayer, C. Scherber, N. Sodhi, I. Steffan-Dewenter, C. Thies, W.H. van der Putten, and C. Westphal. 2012. Landscape moderation of biodiversity patterns and processes - eight hypotheses. Biological Review of the Cambridge Philosophical Society 87:661-685.Turner, M. G. 1989. Landscape Ecology: The effect of pattern on process. Annual Review of Ecology and Systematics 20(1):171-197.

Umber, R. W., and L.D. Harris. 1971. Effects of intensive forestry on succession and wildlife in Florida sandhills. The Journal Series Florida Agricultural Experiment Station Gainesville, 


\section{DRAFT Terrestrial Vertebrate Biodiversity and IFM in the U S}

686-693.

United Nations Environmental Programme (UNEP). 2007. Global environment outlook 4. United Nations Environment Programme, Nairobi, Africa.

U.S. Department of Agriculture Forest Service (USDA). 2005. A strategic assessment of forest biomass and fuel reduction in Western states. General Technical Report RMRS-GTR149. $17 \mathrm{p}$.

Van Deusen, P. C. 1999. Multiple solution harvest scheduling. Silva Fennica 33(3): 207-216.

Van Deusen, P. C. 2001. Scheduling spatial arrangement and harvest simultaneously. Silva Fennica 35(1): 85-92.

Van Deusen, P., T.B. Wigley, and A.A. Lucier. 2012. Cumulative effects of constraints on forest management. Journal of Forestry 110(3):123-128.

Vance, E. D., D. A. Maguire, and R. S. Zalesny Jr. 2010. Research strategies for increasing productivity of intensively managed forest plantations. Journal of Forestry 108: 183-192.

Vanderwel, M. C., J.R. Malcolm, and S.C. Mills. 2007. A meta-analysis of bird responses to uniform partial harvesting across North America. Conservation Biology 21(5):1230 1240.

Verschuyl, J. P., A.J. Hansen, D.B. McWethy, R. Sallabanks, and R.L. Hutto. 2008. Is the effect of forest structure on bird diversity modified by forest productivity? Ecological Applications 18(5):1155-1170.

Verschuyl, J. P., S. Riffell, D. A. Miller, and T. B. Wigley. 2011. Biodiversity response to intensive biomass production from forest thinning in North American forests - a metaanalysis. Forest Ecology and Management 261:221-232.

Vitz, A.C., and A.D. Rodewald. 2006. Can regenerating clearcuts benefit mature-forest songbirds? An examination of post-breeding ecology. Biological Conservation 127:477486.

Wagner, R. G., M. Newton, E.C. Cole, J.H. Miller, and B.D. Shiver. 2004. The role of herbicides for enhancing forest productivity and conserving land for biodiversity in North America. Wildlife Society Bulletin 32(4):1028-1041.

Wampler, C. R., J.K. Frey, D.M. VanLeeuwen, J.C. Boren, and T.T. Baker. 2008. Mammals in mechanically thinned and non-thinned mixed-coniferous forest in the Sacramento Mountains, New Mexico. The Southwestern Naturalist 53(4):431-443.

Wear, D.N. 2013. Forecasts of land use. Pages 45-71 in D.N. Wear and J.G. Greis, eds. The Southern Forest Futures Project: technical report. USDA Forest Service Gen. Tech. Rep. 


\section{DRAFT Terrestrial Vertebrate Biodiversity and IFM in the U S}

SRS-178. 542 p.

Weatherford, P.R., V. L. Tatum, and T. B. Wigley. 2015. Herbicide use patterns on corporate forest lands in the United States, 2011. Technical Bulletin No. 1031. Research Triangle Park, N.C.: National Council for Air and Stream Improvement, Inc.

Wester E.E., and J.W. Kolb. 2008. Impact of natural gas pipeline operation and maintenance on long-term population viability of the threatened gopher tortoise. Pages 499-511 in Goodrich-Mahoney JW, Abrahamson L, Ballard J, Tikalsky S, editors. Eighth International Symposium on Environmental Concerns in Rights-of-Way Management. New York: Elsevier.

Wheat, B. R. 2015. Effects of intercropping switchgrass in managed pine stands on plant communities and white-tailed deer forage production. Mississippi State University, Mississippi State, Mississippi, USA.

White, L. D., L.D. Harris, J.E. Johnston, and D.G. Milchunas. 1976. Impact of site preparation on flatwoods wildlife habitat. Proceedings of the Annual Conference for Southeastern Association of Game and Fish Commissioners 29:347-353.

Wiens, J. A, N.C. Stenseth, B. Vanhorne, and R.A. Ims. 1993. Ecological mechanisms and landscape ecology. Oikos 66(3):369-380.

Wigley, T. B., K.V. Miller, D.S. deCalesta, and M.W. Thomas. 2002. Herbicides as an alternative to prescribed burning for achieving wildlife management objectives. Pages 124 - 138 in W.M. Ford, K.R. Russell, and C.E. Moorman, eds. Proceedings: the role of fire for nongame wildlife management and community restoration: traditional uses and new directions. Gen. Tech. Rep. NE-288. Newtown Square, PA: U.S. Department of Agriculture, Forest Service, Northeastern Research Station. 145 p.

Wigley, T.B. and M.A. Melchiors. 1994. Wildlife habitat and communities in streamside management zones: a literature review for the eastern United States. Pages 100-121 in Proc. conf. riparian ecosystems in the humid U.S.: functions, values and management. National Assoc. Conservation Districts, Washington, DC.

Wilson, M. D., and B. D. Watts. 1999. Response of brown-headed nuthatches to thinning of intensively managed forests. Wilson Bulletin 111:56-60.

Wilson, M. D., and B. D. Watts. 2000. Breeding bird communities in intensively managed forests on the coastal plain of North Carolina. The Chat 64:1-14.

Yahner, R. H. 1988. Changes in wildlife communities near edges. Conservation Biology 2(4):333-339.

Yates, M. D., S.C. Loeb, and D.C. Guynn. 1997. The effect of habitat patch size on small mammal populations. Proceedings of Annual Conference; Southeastern Association of 
Fish and Wildlife Agencies 51(JANUARY): 501-510.

Zobrist, K.W., and T.M. Hinckley. 2005. A literature review of management practices to support increased biodiversity in intensively managed Douglas-fir plantations. Pages A1-A14 in Final Technical Report to the National Commission on Science for Sustainable Forestry (NCSSF).

Zobrist, K.W., T.M. Hinckley, and M.G. Andreu. 2005. A literature review of management practices to support increased biodiversity in intensively managed loblolly intensively managed forests. Pages C1-C16 in Final Technical Report to the National Commission on Science for Sustainable Forestry (NCSSF).

Zutter, B. R., and S.M. Zedaker. 1988. Short-term effects of hexazinone applications on woody species diversity in young Loblolly pine plantations. Forest Ecology and Management 24:183-189.

Zwolak R. A meta-analysis of the effects of wildfire, clearcutting, and partial harvest on the abundance of North American small mammals. Forest Ecology and Management. 2009 Aug 20;258(5):539-45. 
DRAFT Terrestrial Vertebrate Biodiversity and IFM in the U S

Intensive forest management affects terrestrial vertebrates primarily by modifying habitat Effects are species-specific and linked to intensity and extent of habitat modification Landscape context and stand configuration has implications for vertebrate diversity

Negative impacts on vertebrate diversity can often be ameliorated via management practices Intensively managed forest landscapes contribute to conservation of biological diversity 